\title{
Effects of cell-cell crosstalk on gene expression patterns in a cell model of renal cell carcinoma lung metastasis
}

\author{
KATARZYNA KAMINSKA $^{1 *}$, ANNA M. CZARNECKA ${ }^{1 *}$, MOHAMMED IMRAN KHAN $^{1}$, \\ WOJCIECH FENDLER ${ }^{2,3}$, ALEKSANDRA KLEMBA ${ }^{1,4}$, PAWEL KRASOWSKI ${ }^{1,4}$, \\ EWA BARTNIK $^{5,6}$ and CEZARY SZCZYLIK ${ }^{1,7}$
}

\author{
${ }^{1}$ Department of Oncology, Military Institute of Medicine, 04-141 Warsaw; ${ }^{2}$ Department of Biostatistics and \\ Translational Medicine, Medical University of Lodz, 92-215 Lodz, Poland; ${ }^{3}$ Department of Radiation Oncology, \\ Dana-Farber Cancer Institute, Boston, MA 02115, USA; ${ }^{4}$ College of Inter-Faculty Individual Studies in Mathematics \\ and Natural Sciences, University of Warsaw, 02-097 Warsaw; ${ }^{5}$ Institute of Genetics and Biotechnology, Faculty of Biology, \\ University of Warsaw; ${ }^{6}$ Institute of Biochemistry and Biophysics, Polish Academy of Sciences, 02-106 Warsaw, Poland
}

Received February 12, 2017; Accepted December 4, 2017

DOI: $10.3892 /$ ijo.2017.4234

\begin{abstract}
The median survival rate of patients with metastatic renal carcinoma is approximately 10 to 12 months, with up to $50 \%$ of patients developing metastases in the lung parenchyma. The molecular basis for metastatic development remains unclear. In the present study, we used renal cell carcinoma (RCC) cells and bronchial epithelial cells, representing metastasis target organ cells, conditioned medium and co-culture models to identify specific gene expression changes responsible for cancer cell viability in a metastatic microenvironment. RCC cell proliferation and migration increased when the culture was supplemented with conditioned medium from lung fibroblasts or pleural epithelial cells. Healthy epithelial cells were, in turn, also stimulated with conditioned medium from RCC cell lines. The mitogen-activated protein kinase (MAPK), interleukin (IL)-6, and phosphatidylinositol 4,5-bisphosphate (PIP2) signaling pathways were identified as deregulated
\end{abstract}

Correspondence to: Dr Anna M. Czarnecka, Department of Oncology, Military Institute of Medicine, 128 Szaserow Street, 04-141 Warsaw, Poland

E-mail: anna.czarnecka@gmail.com

Present address: ${ }^{7}$ Warsaw Medical University, Zwirki i Wigury 61, 02-091 Warsaw, Poland

*Contributed equally

Abbreviations: ccRCC, clear cell renal cell carcinoma; HKCSC, human kidney cancer stem cells; RCC, renal cell carcinoma; TGF- $\beta$, transforming growth factor- $\beta$; TME, tumor microenvironment; EGFR/MAPK, epidermal growth factor receptor/mitogen-activated protein kinase; IL-6, interleukin 6; FGFs, fibroblast growth factors; VEGF, vascular endothelial growth factor

Key words: renal cell carcinoma, metastasis, tumor microenvironment, microarray, gene expression, signaling pathways, lung upon cell-cell interaction. Thus, cell-cell communication may contribute to the development of the metastatic niche. The identified deregulated signaling pathways may be considered as potential therapeutic targets in metastatic renal carcinoma.

\section{Introduction}

In total, $85 \%$ of renal tumors are malignant, with the most common type of renal cell carcinoma (RCC), clear cell RCC (ccRCC), diagnosed in $>75 \%$ of patients $(1,2)$. RCC is characterized by a high mortality rate and is highly resistant to standard chemotherapy or radiotherapy. RCC can also recur at any time following a nephrectomy ( $>15$ years) and metastasizes both via the lymphatic and venous routes. RCC is highly metastatic, and in $75 \%$ of cases, metachronous tumors develop in the lungs, liver, bones, adrenal glands, pancreas, brain, thyroid gland, skin, or ureter (3). In particular, metastases develop in the lung parenchyma in up to $60 \%$ of the patients, up to $40 \%$ in bone, $40 \%$ in the liver and 5\% in the brain (4). Moreover, in $25-30 \%$ of patients with ccRCC, metastasis is already present at the time of initial diagnosis; this is associated with a high mortality rate (5). Only $10 \%$ of patients diagnosed with metastatic disease survive for 5 years, in comparison to $60 \%$ of patients who survive for that period of time if the disease is localized $(6,7)$. The molecular events responsible for metastatic spread and secondary tumor development are not yet understood and remain a challenge in current research.

Currently, the great importance of the tumor microenvironment (TME) is embodied in the concept that cancer cells need to conscript and corrupt resident and recruited normal cell types for local growth, invasion and migration (8). Non-malignant stromal cells create a specific microenvironment altering the neoplastic properties of tumor cells (9). Primary tumors secrete factors that modify the microenvironment of distant organs in order to create a fertile environment for subsequent metastatic cancer cell colonization. In conclusion, the TME drives the process of tumor progression, metastatic dissemination and drug resistance (9). 
The aim of this study was to explore RCC gene expression patterns and signaling alterations in a microenvironmental lung metastasis model. To evaluate paracrine interactions between cancerous and normal cells, conditioned media and a co-culture model were developed and high throughput cDNA microarray analysis was subsequently employed to investigate the expression patterns induced by the cancer cells and reciprocated/propagated by the TME. RCC cells and normal cells of the metastatic target organ were co-cultured, and their gene expression patterns were compared to RCC and normal cells cultured separately. In particular, to examine the effects of cell-cell interactions between RCC and normal lung cells on renal carcinoma gene expression profiles, normal human bronchial epithelial cells (NL-20) were examined in interaction with ACHN cells derived from the malignant pleural effusion of males with metastatic renal carcinoma and Caki-2 cells derived from a primary kidney carcinoma. Microarray analysis of the gene expression profiles was used to identify pathways involved in cancer cell viability in the metastatic tumor niche (10).

\section{Materials and methods}

Cell culture. Human RCC cell lines from primary (Caki-2, RCC6, 786-O, 769-P, SMKT-R2) and metastatic tumors (ACHN, Caki-1) [according to our meta-analysis (11), both the ACHN and Caki-2 cell lines were found to be non-clear renal cell carcinoma cells] and human normal cell lines, including lung/bronchus epithelial cells (NL-20/CRL-2503), fibroblasts (LeSa/LL 86/CCL-190), kidney epithelial cells (ASE-5063), primary renal proximal tubule epithelial cells (PRPTECs/PCS-400-010) and epithelial mesothelial cells (MeT5A/CRL9444), were maintained at $37^{\circ} \mathrm{C}$ in the presence of $5 \% \mathrm{CO}_{2}$ in an RPMI-1460 medium with GlutaMAX ${ }^{\mathrm{TM}}$ (Life Technologies, Carlsbad, CA, USA), $10 \%$ fetal bovine serum (Biochrom GmbH, Cambridge, UK), and antibiotics (pen/ strep) (Amersco, Solon, OH, USA). Human kidney epithelial cells derived from whole kidneys from a single donor (ASE-5063 cells) were purchased from Applied StemCell, Inc. (Menlo Park, CA, USA). The SMKT-R2 (RRID:CVCL_A750) cell line was a kind gift from Professor Taiji Tsukamoto (School of Medicine, Sapporo Medical University, Sapporo, Japan) (12). The RCC6 (CVCL_E056) cell line was a kind gift from Professor Salem Chouaib (INSERM, Institut Gustave Roussy, Villejuif, France) (13). All other cell lines were purchased from the American Type Culture Collection Global Bioresource Center (ATCC; Manassas, VA, USA). Normoxia was defined as $21 \% \mathrm{O}_{2}$ in culture, while hypoxia as $2 \% \mathrm{O}_{2}$.

Following $24 \mathrm{~h}$ of cell culture, the medium was collected and then referred to as conditioned medium (CM) (14). CM was used raw and filtered through syringe filters with $0.22-\mu \mathrm{m}$ or $0.45-\mu \mathrm{m}$ pore diameters (EuroClone $\mathrm{SpA}$, Pero, MI, Italy). CM was then diluted $(50 \%, 30 \%, 10 \%)$ with fresh RPMI medium with serum and used in growth stimulation experiments. The cancer cells were treated with CM from normal cells, and normal cells were stimulated by $\mathrm{CM}$ derived from cancer cells.

Co-culture. For cell co-culture, 24-well plates were used with transparent polyester inserts with a $0.4-\mu \mathrm{m}$ pore size
(Greiner Bio-One GmbH, Frickenhausen, Germany). The seeding density was optimized for the proliferation rate of each cell line. For the final gene expression analysis described below, renal carcinoma ACHN $\left(0.7 \times 10^{5}\right.$ cells/well) or Caki-2 $\left(0.8 \times 10^{5}\right.$ cells/well) cells were plated in 24 -well plates, while bronchial epithelial NL-20 cells $\left(1.3 \times 10^{5}\right.$ cells/co-culture insert) were plated in inserts (in empty plates). The cells were cultured for $24 \mathrm{~h}$ to allow attachment. After $24 \mathrm{~h}$, the inserts with NL-20 cells were placed in pre-seeded plates for ACHN or Caki-2 co-culture.

Wound healing assay. The CytoSelect ${ }^{\mathrm{TM}}$ 24-well wound healing assay (Cell Biolabs, Inc., San Diego, CA, USA) gap closure migration assays were used as per the manufacturer's instructions. Light microscopy with a Nikon TMS-F inverted microscope and a Delta Optical HDCE-30C 3MP camera (Delta Optical, Nowe Osiny, Poland) were used for imaging.

Cell proliferation estimation. The cells were seeded in 96-well plates and cultured under standard conditions $\left(37^{\circ} \mathrm{C}, 5 \% \mathrm{CO}_{2}\right)$ in regular RPMI/FBS medium (control) or CM (proliferation induction analysis). Subsequently, cell proliferation was quantified after 24, 48, 72, 96, 120 and $144 \mathrm{~h}$ (referred as to days 1-6). An alamarBlue ${ }^{\circledR}$ (resazurin) (Life Technologies) assay was performed as per the manufacturer's instructions to quantitatively measure cell viability (15). The absorbance of alamarBlue ${ }^{\circledR}$ was read using a Multiskan ${ }^{\mathrm{TM}}$ GO Microplate spectrophotometer (Thermo Fisher Scientific, Waltham, MA, USA) at 570 and $600 \mathrm{~nm}$. The absorbance obtained from readings at 570 and $600 \mathrm{~nm}$ was then calculated to the percentage reduction of alamarBlue ${ }^{\circledR}$, as follows:

$$
\% \text { of alamarBlue reduction }=\frac{(\mathrm{O} 2 * \mathrm{~A} 1)-(\mathrm{O} 1 * \mathrm{~A} 2)}{(\mathrm{R} 1 * \mathrm{~N} 2)-(\mathrm{R} 2 * \mathrm{~N} 1)} \times 100 \%
$$

where $\mathrm{O} 1=$ molar extinction coefficient of oxidized alamarBlue ${ }^{\circledR}$ at $570 \mathrm{~nm}=80586, \mathrm{O} 2=\mathrm{E}$ of oxidized alamarBlue ${ }^{\circledR}$ at $600 \mathrm{~nm}$ $=117216, \mathrm{R} 1=\mathrm{E}$ of reduced alamarBlue ${ }^{\circledR}$ at $570 \mathrm{~nm}=155677$, $\mathrm{R} 2=\mathrm{E}$ of reduced alamarBlue ${ }^{\circledR}$ at $600 \mathrm{~nm}=14652, \mathrm{~A} 1=$ absorbance of test wells at $570 \mathrm{~nm}, \mathrm{~A} 2=$ absorbance of test wells at $600 \mathrm{~nm}, \mathrm{~N} 1=$ absorbance of negative control well (media plus alamarBlue ${ }^{\circledR}$ ) at $570 \mathrm{~nm}$, and N2 = absorbance of negative control well (media plus alamarBlue ${ }^{\circledR}$ ) at $600 \mathrm{~nm}$. It was read by a Multiskan GO microplate reader and analyzed using the SkanIt ${ }^{\mathrm{TM}}$ software package (Thermo Fisher Scientific).

In the co-culture model, the cells were incubated for $24 \mathrm{~h}$ after insert placement before the first measurement was taken. After that, measurements were taken every $24 \mathrm{~h}$ (days 2-6). All experiments were run in 5 replicates.

The cells cultured with blocker of the interleukin (IL)6sR/IL6 complex (recombinant human gp130 protein) were used as negative controls, in order to inhibit the IL-6-dependent proliferation of cells in the presence of human IL-6 R $\alpha$ (Research and Diagnostic Systems, Inc., Minneapolis, MN, USA).

Gene expression analysis. Total RNA was extracted using the Syngen Blood/Cell RNA Mini kit from co-cultured cell lines after day 5 as per the manufacturer's instructions (Syngen, Wroclaw, Poland). Total RNA was purified with the RNase-Free DNase Set (Qiagen, Hilden, Germany) as per the 
manufacturer's instructions. The quantity and quality of RNA samples were estimated with the Nanodrop spectrophotometer ND-1000 (NanoDrop Products, Wilmington, DE, USA) and the 2100 Bioanalyzer microcapillary electrophoresis system (Agilent Technologies, Santa Clara, CA, USA). For analysis, high quality (260/280 - 2.1 RIN>9) samples were selected.

In total, $50 \mathrm{ng}$ of total RNA from each sample were reverse transcribed into cDNA, amplified, and labeled with cyanine 3 or 5 with Two-Color Low Input Quick Amp Labeling Kits (Agilent Technologies). The resulting cDNA was hybridized with a $44 \mathrm{~K}$ Agilent whole genome oligo-microarray in Agilent's SureHyb Hybridization Chambers in accordance with the manufacturer's instrutions. The Agilent whole genome oligo-microarray covers $41,000^{+}$unique human genes and transcripts, all with public domain annotations, with content sourced from RefSeq, Golden Path Ensembl Unigene Human Genome (Build 33), and GenBank databases, and over $70 \%$ of the represented probes are validated by Agilent's laboratory validation process, with $4 \times 44 \mathrm{~K}$ slide formats printed using Agilent's 60-mer SurePrint technology. Following hybridization and washing, the processed slides were scanned with the Agilent DNA microarray scanner (part number G2565CA) using settings recommended by Agilent Technologies for microplate readers.

Protein expression analysis. Total protein was extracted with RIPA buffer for cell lysis and protein solubilization (SigmaAldrich, St. Louis, MO, USA) with protease inhibitor cocktail (Sigma-Aldrich). The Bio-Rad protein assay (Bio-Rad,Hercules, CA, USA) based on the method of Bradford was used for protein quantification with an absorbance measurement at $595 \mathrm{~nm}$ with Multiscan GO (Thermo Fisher Scientific). The IL6 (human) ELISA kit (KA0123), IL6R (human) ELISA kit (KA0124) and IL6R (human) ELISA kit (KA0523) (all from Abnova, Walnut, CA, USA) were used for the measurement of IL-6 and IL-6R in medium from healthy and RCC cells. In normal cells cultured in control medium and in $\mathrm{CM}$ following incubation of RCC cells, the levels of IL-6R, glycoprotein (gp)130, signal transducer and activator of transcription 3 (STAT3) and activated p-STAT3 were examined by western blot analysis with a Mini-PROTEAN ${ }^{\circledR}$ TGX $^{\mathrm{TM}}$ Precast Polyacrylamide Gels run with Bio-Rad Mini Protean Tetra Cell (Bio-Rad) and Pierce Fast Semi-dry Blotter on Low-fluorescence PVDF Transfer Membrane (Thermo Fisher Scientific). IL-6 antibody (E-4; sc-28343), IL-6R $\alpha$ antibody (D-8; sc-374259) (both from Santa Cruz Biotechnology, Dallas, TX, USA), STAT3 antibody (9D8; MA1-13042), p-STAT3 pTyr705 antibody (G.374.10; MA5-11189) and CD130/gp130 antibody (PA5-28932) (all from Thermo Fisher Scientific) were used as per the manufacturer's dilutions 1:100-1:100, respectively and probed overnight at $4^{\circ} \mathrm{C}$. Secondary anti-mouse IgG (whole molecule)-alkaline phosphatase-labeled antibody produced in goat [A3562] $(1: 7,000)$ was incubated for $2 \mathrm{~h}$ and detected with SIGMA FAST ${ }^{\mathrm{TM}}$ BCIP/ NBT (5-Bromo-4-chloro-3-indolyl phosphate/Nitro blue tetrazolium) (Sigma-Aldrich) and the signal was compared with a PageRuler Prestained Protein Ladder, 10-170 kDa (Thermo Fisher Scientific).

Data analysis and statistical analysis. Agilent Feature Extraction Software version 10.5.1.1 (Agilent Technologies) was used to extract the signal intensity values from each gene chip, and the resulting text files were imported into the Agilent GeneSpring GX software version 13.0 (Agilent Technologies) for further analysis. The microarray data sets normalization, quality control, principal component analysis, and filtered-on flags (detected and not detected) were performed before data analysis. In pair-wise correlation analysis, differentially expressed genes (DEGs) were identified through fold-change screening by comparing cells cultured in 2D and co-cultured cell line (normal lung cell line vs lung cells induced by cancer cell). Gene expression profiling of microarray data was analyzed with moderate t-test and multiple testing corrected with the Westfall and Young permutation. The P-value computation was conducted with asymptotic method (16). The statistical significance was assessed at $\mathrm{P}<0.05$, and a fold change cut-off $\geq 2.0$ (up-/downregulated) was selected to identify genes that were differentially expressed, as previously described $(17,18)$.

To select target genes of interest both statistically and biologically, a pathway analysis was performed using Ingenuity Pathway Analysis (IPA; Qiagen) (19). IPA was used to evaluate potential gene networks activated in analysed cells. Lists of genes with known gene symbols (HUGO) and their corresponding expression values were uploaded into the IPA software. Gene symbols were mapped to their corresponding gene object in the Ingenuity Pathways Knowledge Base (IKB). Networks of these genes were generated based on their connectivity and assigned an IPA score. Analysis was used to compute a score for each network according to the fit of that network to the user-defined set of focus genes. The score was derived from a P-value and indicates the likelihood of the gene or protein in a network being found to interact due to random chance. The IPS score was defined as a numerical value used to rank networks according to relevance to genes in the analyzed dataset defined by number of genes in the network and the size of the network. The networks identified are presented in figures showing interactions between molecules (genes). Genes are represented as nodes in the networks. The intensity of the node color indicates the degree of up- or downregulation (upregulation in red, downregulation in green). Canonical pathway analysis was used to identify the signaling pathways which were most significant in the analyzed data set. The significance of the association between the data set and the canonical pathway was determined based on the following 2 parameters: i) A ratio of the number of genes from the data set that map to the pathway divided by the total number of genes that map to the canonical pathway; and ii) Fisher's exact test P-value for the random association between genes in the data set and the canonical pathway, as previously described (20). In the next step the upstream regulators in the IPA analysis were defined and listed as molecules that potentially affect the expression of other molecules (genes). Analysis was based on the expected causal effects between upstream regulators and target genes, and the expected interaction effects were derived from IKB. Causal networks analysis was used to integrate previously observed cause-effect relationships reported in IKB, describing the direction of effects with downstream effectors impacting cell biology. Regulator effects networks analysis was used to explain how predicted activated and inhibited upstream regulators cause increases or decreases in functional and phenotypic effects of the cells and identified 

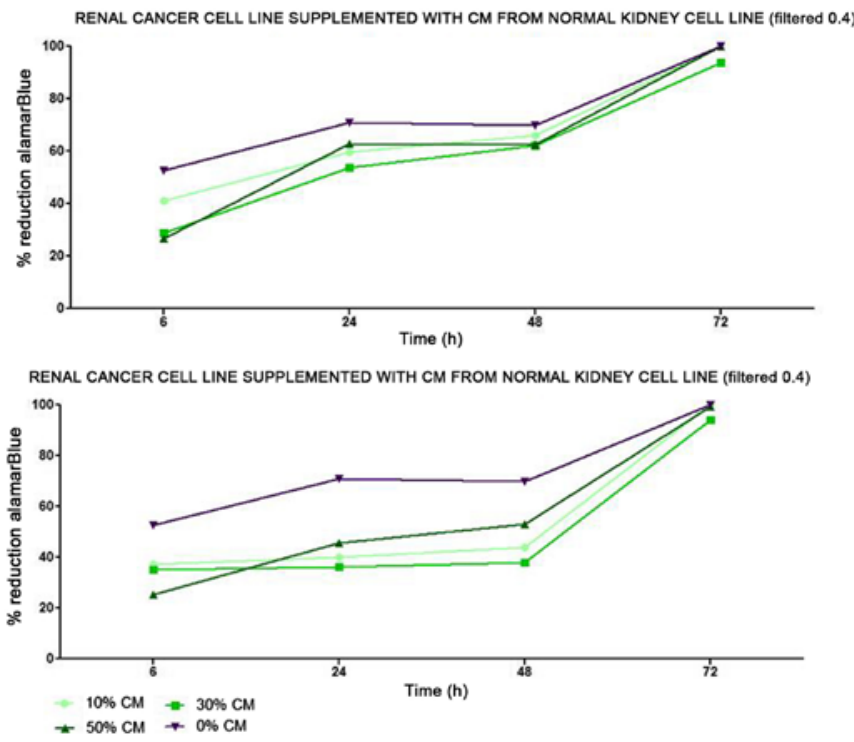

Figure 1. Influence of conditioned medium from normal renal cells on the proliferation of RCC cells. Conditioned medium was used at 10, 30 and $50 \%$ and the alamarBlue reduction was measured.

the most biologically significant genes referred to as analysisready molecules (21). A score of $\geq 2$ was defined as having at least a $99 \%$ confidence of not being generated by random chance alone.

Gene Ontology (GO) and WikiPathways data sources were used to recognize up- and downregulated signaling pathways and processes (22-24). Cell growth data were subjected to a two-way analysis of variance (ANOVA) followed by Bonferroni's post hoc test with the use of GraphPad Prism 5.0 software (GraphPad Software Inc., La Jolla, CA, USA). All data are expressed as the means \pm standard deviation from at least 3 replicates. A P-value $<0.05$ was considered to indicate a statistically significant difference in any experiment.

\section{Results}

Renal carcinoma cell lines are induced by metastatic target organ cells. Renal cancer cell line cultures (786-0, Caki-1, Caki-2, RCC6, SMKT-R2, ACHN) were supplemented with $\mathrm{CM}$ from lung metastatic target organ cell lines, including a normal fibroblast cell line (LeSa) and pleural epithelial cells (NL-20). At the same time, the RCC cells were also cultured with CM from normal renal cells (RPTEC/ASE-5063) as primary tumor site internal induction control. Supplementation with $\mathrm{CM}$ from the normal kidney (proximal tubule) cells slightly decreased RCC cell proliferation (Fig. 1). On the other hand, RCC cell proliferation was increased on day 3 (72 h) when the culture was supplemented with $10 \% \mathrm{CM}$ from metastatic target organ fibroblasts; however, the effect was transient and was lost on day 6. At the same time, 50\% CM from pleural epithelial NL-20 cells significantly and stably increased the RCC cell proliferation rate (Fig. 2). Moreover, in the wound healing assay, supplementation with CM from lung fibroblasts and pleural cells was found to increase the RCC cell migratory potential (Fig. 3) defined by the wound closure velocity. The migration rate increased with the concentration of the CM (Figs. 3 and 4). At the edge of the scratch, the cancer
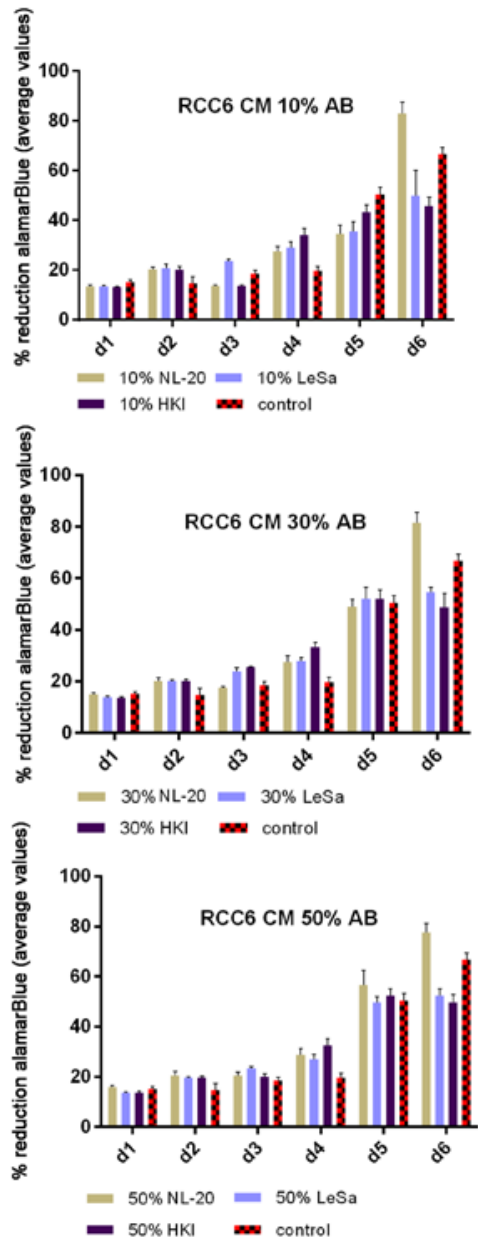

Figure 2. Influence of conditioned medium from normal cells on the proliferation of RCC cells. Conditioned medium was used at 10, 30 and 50\% and the alamarBlue reduction was measured. RCC6, RCC cell lines from primary tumor; NL-20, indicates normal pleural epithelial cells from human normal lungs; LeSa, indicates fibroblasts derived from human normal lungs; HKI, indicates proximal tubule cells (RPTECs) derived from human normal kidney; d, day.

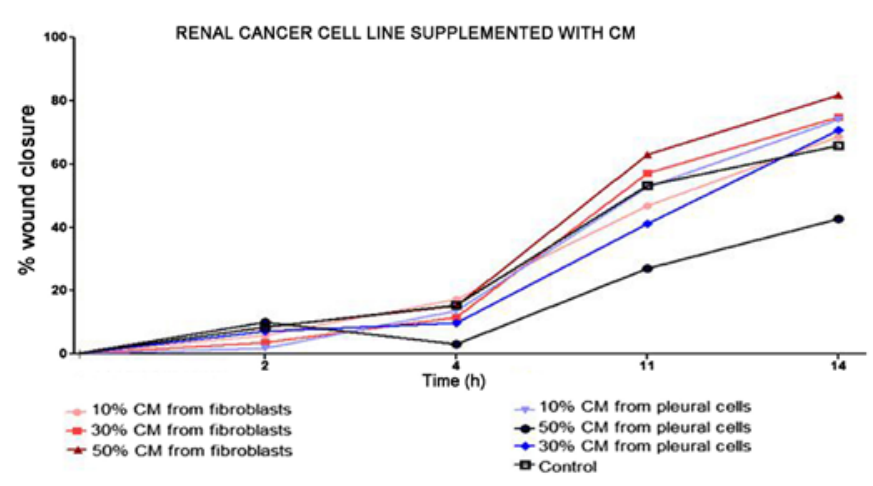

Figure 3. Influence of conditioned medium (CM) from metastatic target tissue on the migration of the RCC cell line. NL-20, indicates normal pleural epithelial cells from human normal lungs; LeSa, indicates fibroblasts derived from healthy human lungs. CM was used at 10, 30 and $50 \%$ and wound closure was measured.

cells formed a loosely connected population without uniform velocity of the cell front. At regions with less confluency, cell populations of heterogeneous morphology were observed, including cells with a fibroblast-like morphology. 

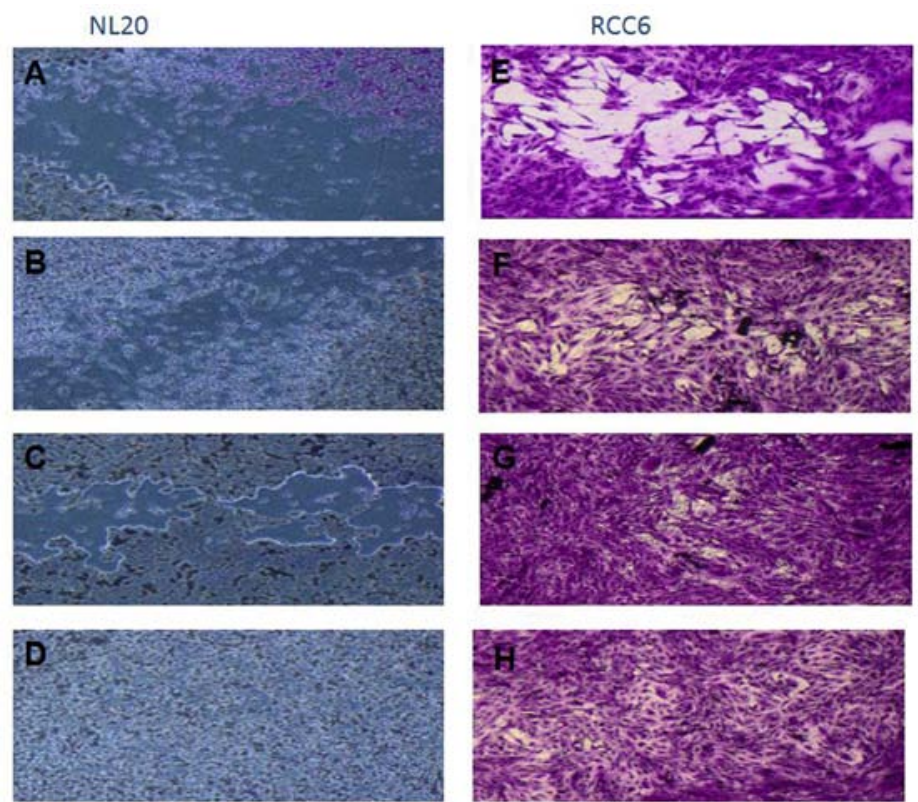

Figure 4. Migration assay of cells stimulated with CM. RCC6 cell line was from a renal primary tumor and NL-20 cells are normal pleural epithelial cells from human normal lungs. The effect of conditioned medium (CM) collected after $24 \mathrm{~h}$ of culture on NL-20 (A-D) and RCC6 (E-H) cells was measured. (A and E) Control cell growth with 0\% CM; (B) CM from ACHN cells; (C) CM from SMKT-R2 cells; (D) CM from RCC6 cells; (F) 10\% CM from LeSa cells; (G) 30\% CM from LeSa cells; and (H) 50\% CM from LeSa cells. Conditioned media from SMKT-R2 cells, RCC cell lines from primary tumor; ACHN, RCC cell lines from metastatic site (lung); LeSa, fibroblasts derived from healthy human lungs; and RCC6 cell line from renal primary tumor were tested.
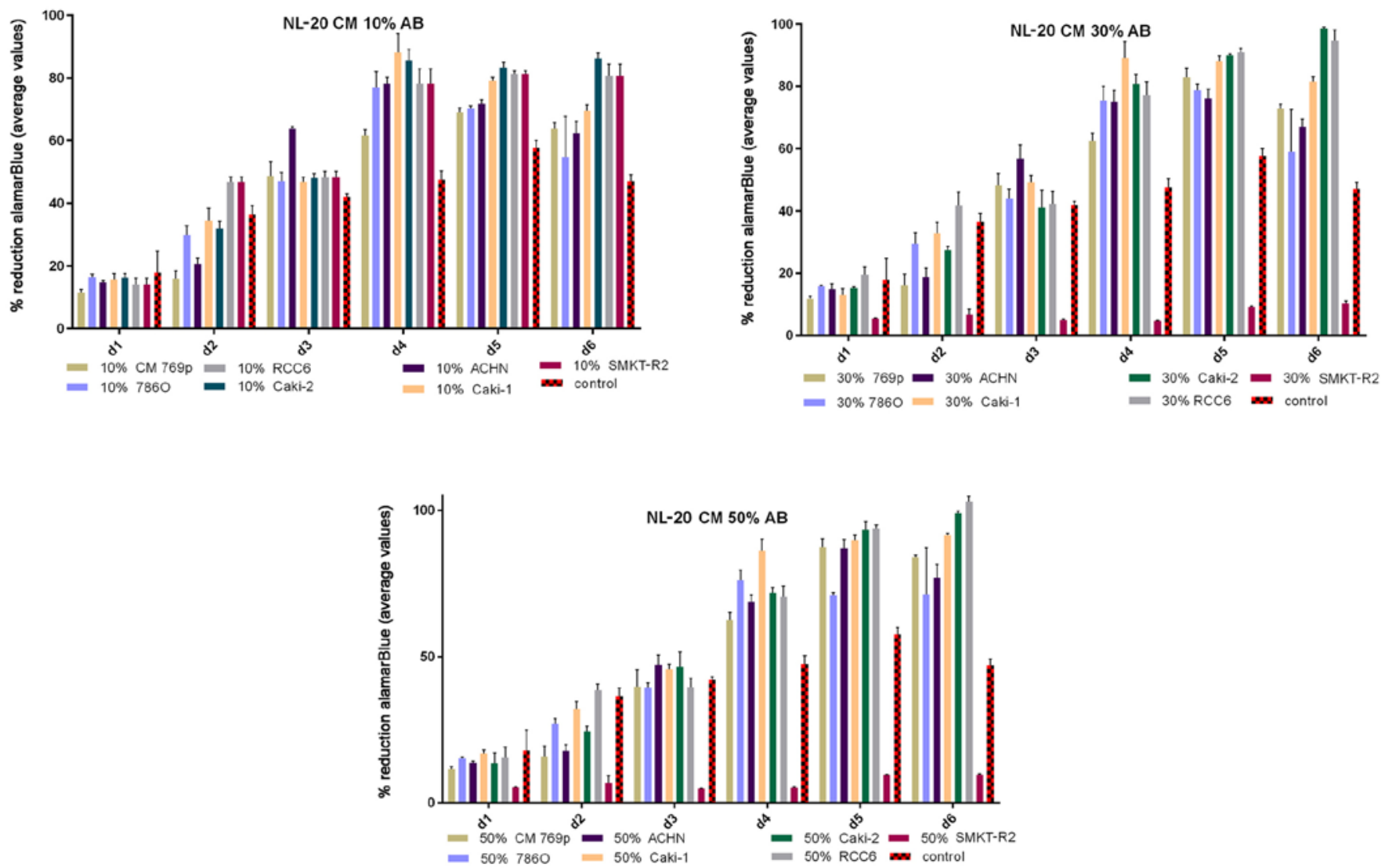

Figure 5. Healthy epithelial cells from lungs stimulated with conditioned medium from RCC cell lines. NL-20, epithelial cells derived from human healthy lungs were induced with conditioned medium from renal cell cancer cells, including 769P, 786O, Caki-2 and RCC6. SMKT-R2, cells from primary tumor, and ACHN and Caki-1 cells from metastatic sites were used. d, day.

The effect of CM from cancer cells was tested on normal cells (LeSa, Met-5A, NL-20, RPTEC/ASE-5063) and the
NL-20 cells were found to be stimulated by CM from the RCC cell lines (Fig. 5). Moreover, migration assay indicated that 


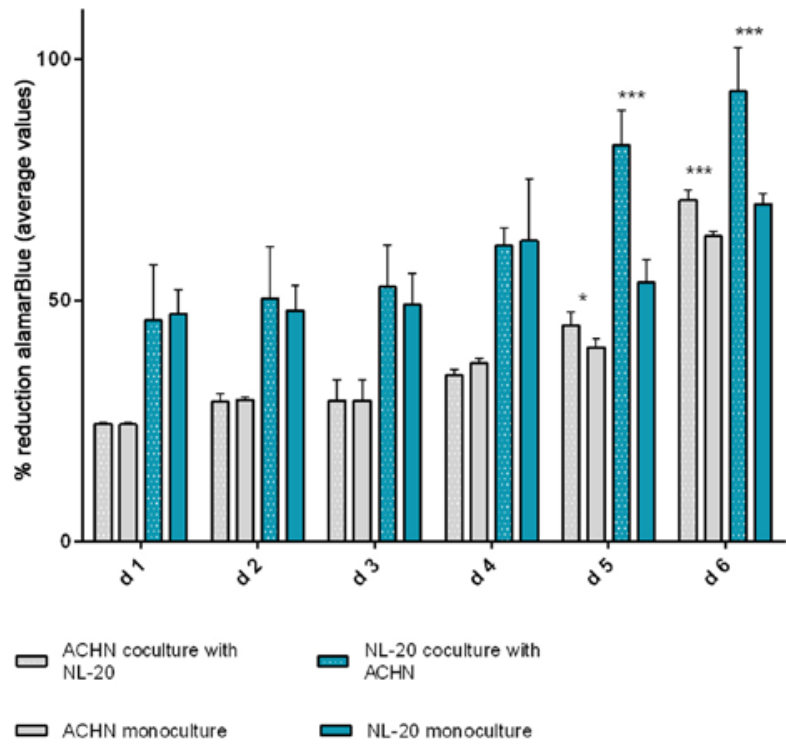

Figure 6. Effects of co-culture of ACHN and NL-20 cells on proliferation. alamarBlue assay of NL-20 and ACHN cell proliferation upon interaction and in monoculture. $d$, day. ${ }^{* * *} \mathrm{P}<0.001$ and ${ }^{*} \mathrm{P}<0.05$.

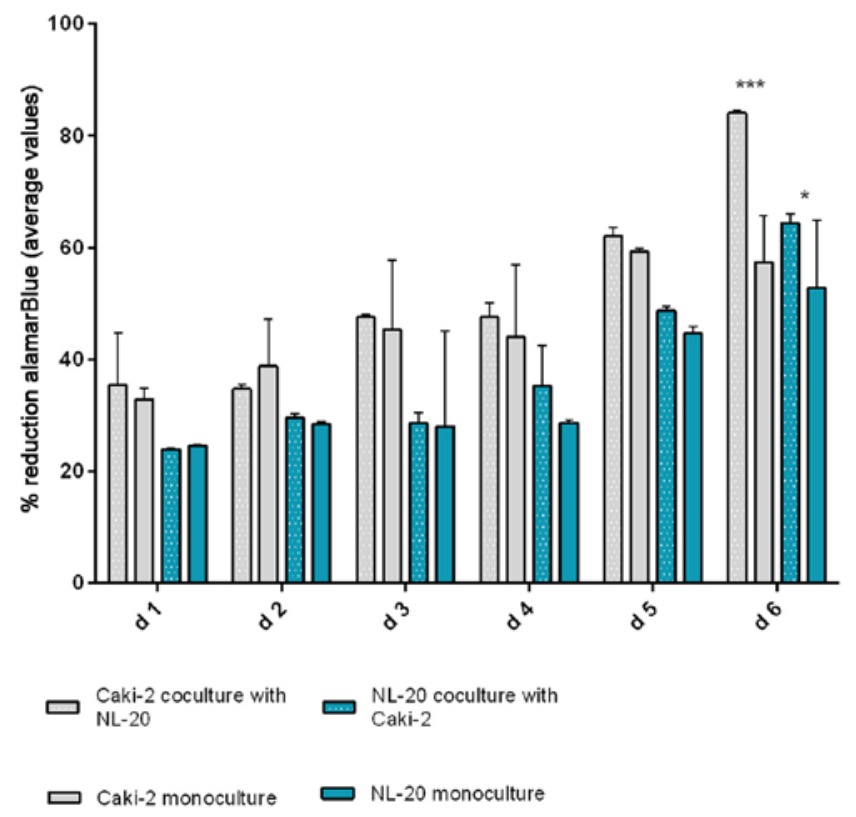

Figure 7. Effects of co-culture of Caki-2 and NL-20 cells on proliferation. alamarBlue assay of NL-20 and Caki-2 cell proliferation upon interaction and in monoculture. $d$, day. ${ }^{* * *} \mathrm{P}<0.001$ and ${ }^{*} \mathrm{P}<0.05$.

NL-20 cell motility was induced by CM from cancer cells and that the cell migratory distances increased upon stimulation. The migration pattern of NL-20 as continuous sheet of cells or a tight layer of cells mimics the behavior of epithelial cells during migration in vivo (Fig. 4).

The Caki-2 and ACHN RCC cells that were most significantly stimulated by the CM from NL-20 normal cell lines, and that in turn most significantly induced NL-20 cells were selected for further co-culture and gene expression analyses to represent both the primary and metastatic RCC tumor model.

In the second step, the co-culture of cell line pairs revealed a statistically significant effect of cell-cell communication
Table I. Analysis of the process of ontology deregulation upon the interaction of normal epithelial NL-20 pleural cells with renal cell cancer cells (both Caki-2 and ACHN cells).

\begin{tabular}{ll} 
GO Term & P-value \\
\hline Terpenoid transport & $7.95 \mathrm{E}-05$ \\
Isoprenoid transport & $7.95 \mathrm{E}-05$ \\
Retinol transport & $7.95 \mathrm{E}-05$ \\
Mediator complex binding & $4.71 \mathrm{E}-04$ \\
Vitamin transporter activity & $7.15 \mathrm{E}-04$ \\
Heart trabecula morphogenesis & 0.001237 \\
Positive regulation of Arp2/3 complex-mediated & 0.00162 \\
actin nucleation &
\end{tabular}

Negative regulation of fatty acid oxidation

0.00162

Positive regulation of actin nucleation

0.002148

Vitamin transport

0.002161

Activation of MAPKKK activity

0.002745

Histone H3-K4 trimethylation

0.003411

Regulation of heart growth

0.003426

Cellular response to calcium ion

0.003723

Trabecula morphogenesis

0.004035

Ventricular trabecula myocardium

0.004145

morphogenesis

Folic acid binding

0.004145

Regulation of action potential

0.004145

Detection of mechanical stimulus

0.004706

Gland development

0.004804

Top 20 annotations for induced NL-20 cells (NL-20 + Caki-2 and NL-20 + ACHN cells) are selected.

between RCC and lung cell lines. Significant differences in the cell proliferation rate and cell number were observed after at least 5 days of culture. The effect was shown in the ACHN cells co-cultured with the NL-20 cells when compared with the ACHN cells in a monoculture $(\mathrm{P}<0.05)$ and the NL-20 cells in monoculture $(\mathrm{P}<0.001)$ (Fig. 6). A stimulatory effect was obtained in both culture baso-lateral orientations when NL-20 cells were co-cultured with the ACHN cells, and when the ACHN cells were co-cultured with the NL-20 cells. The same effect was reported for the Caki-2 and NL-20 cell pairs on day 5. Caki-2 co-culture with the NL-20 cells induced proliferation when compared to Caki-2 cell monoculture $(\mathrm{P}<0.001)$ and NL-20 monoculture $(\mathrm{P}<0.05)$ (Fig. 7). Based on the obtained results from both pairs of cell lines (NL-20 and Caki-2, N + C; NL-20 and ACHN, N + A), day 5 was selected for RNA and protein extraction for further gene expression analysis.

Gene expression is deregulated upon the interaction of primary RCC tumor cells with normal pleural cells. A significant difference in expression was found between normal cells induced by different cancer cells $(\mathrm{N}+\mathrm{C}$ vs. $\mathrm{N}+\mathrm{A}$, Tables $\mathrm{I}-\mathrm{V})$, 
Table II. Analysis of biological pathway (WikiPathways) deregulation upon the interaction of normal epithelial NL-20 pleural cells with renal cell carcinoma cells, Caki-2.

\begin{tabular}{|c|c|c|}
\hline Pathway name & Pathway no. & $\mathrm{P}$-value \\
\hline $\begin{array}{l}\text { Metabolism of angiotensino- } \\
\text { gen to angiotensins }\end{array}$ & WP2729 76948 & 0.035113286 \\
\hline $\begin{array}{l}\text { Extrinsic pathway for } \\
\text { apoptosis }\end{array}$ & WP1814 77023 & 0.04881313 \\
\hline $\begin{array}{l}\text { Translocation of GLUT4 to } \\
\text { the plasma membrane }\end{array}$ & WP2777 77058 & 0.014380898 \\
\hline $\begin{array}{l}\text { Transcriptional regulation } \\
\text { of white adipocyte } \\
\text { differentiation }\end{array}$ & WP2751 76992 & 0.028172182 \\
\hline Effects of PIP2 hydrolysis & WP1809 76979 & 0.045406394 \\
\hline $\begin{array}{l}\text { Signaling by the B cell } \\
\text { receptor (BCR) }\end{array}$ & WP2746 76984 & 0.055310383 \\
\hline Prolactin receptor signaling & WP2678 78711 & 0.001118844 \\
\hline Syndecan interactions & WP2787 77077 & 0.055590402 \\
\hline $\begin{array}{l}\text { Cytosolic sensors of } \\
\text { pathogen-associated DNA }\end{array}$ & WP2794 77085 & 0.020168457 \\
\hline $\begin{array}{l}\text { Advanced glycosylation } \\
\text { endproduct receptor signaling }\end{array}$ & WP1781 76860 & 0.04198754 \\
\hline
\end{tabular}

Pathways deregulated in NL-20 cells are shown.

Table III. Analysis of biological pathway (WikiPathways) deregulation upon the interaction of normal epithelial NL-20 pleural cells with renal cell cancer cells ACHN.

\begin{tabular}{|c|c|c|}
\hline Pathway name & Pathway no. & P-value \\
\hline Interleukin-6 signaling & WP2704 76915 & 0.04469201 \\
\hline $\begin{array}{l}\text { Activation of gene } \\
\text { expression by SREBP }\end{array}$ & WP2706 76917 & 0.006162484 \\
\hline
\end{tabular}

(SREBF)

Opioid signaling

Fc-gamma receptor (FCGR)

dependent phagocytosis

DAG and IP3 signaling

GPCR ligand binding

GPCR downstream signaling

Transcriptional activity of

SMAD2-SMAD3-SMAD4

heterotrimer

Fatty acid, triacylglycerol, and ketone body metabolism

Generic transcription pathway

WP1978 769190.051675532

WP2719 769360.006467762

WP2688 $76890 \quad 0.016291482$

WP1825 769770.030907014

WP1824 769100.0152681

WP2755 $77005 \quad 0.030645737$

WP1817 $77087 \quad 0.04063944$

WP1822 $77033 \quad 0.016291482$

Pathways deregulated in NL-20 cells are shown.

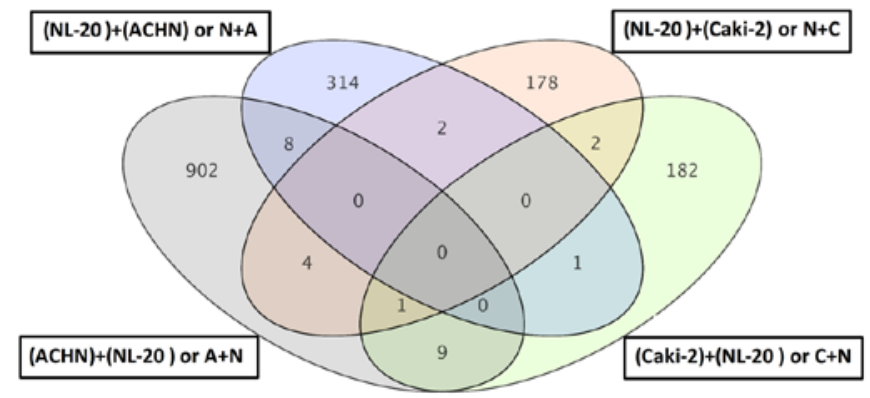

Figure 8. Differentially expressed genes between the Caki-2, ACHN, NL-20 cells and co-cultured cells was obtained by GeneSpring GX 13.0 software.

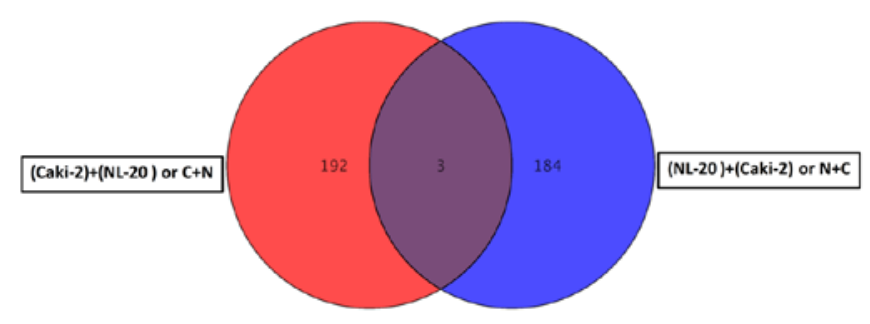

Figure 9. Differentially expressed genes between NL20 cells vs. NL-20 + Caki-2 co-culture and Caki-2 cells vs. Caki- 2 + NL-20 co-culture.

cancer cell lines induced by normal cells $(\mathrm{C}+\mathrm{N}$ vs. $\mathrm{A}+\mathrm{N}$, Tables VI-IX), as well as between co-cultures and Caki-2 monoculture or NL-20 monoculture (Fig. 8).

For primary tumor cells the two interactions, Caki- 2 cell induction by NL-20 cells (referred to as $\mathrm{C}+\mathrm{N}$ ) and NL-20 cell induction by Caki-2 cells (referred to as $\mathrm{N}+\mathrm{C}$ ), resulted in the deregulation of multiple signaling pathways in both analyzed cell lines, in normal NL-20 cells (Tables I and II), as well as in Caki-2 cancer cells (Tables VI and VII). This interaction of primary tumor-derived RCC tumor cells (Caki-2) with normal pleural cells (NL-20), modelling first interaction upon formation of metastasis, resulted in the deregulation of specific genes (Figs. 8 and 9). As the interaction was reciprocal, both interactions, Caki-2 cells inducing NL-20 cells $(\mathrm{N}+\mathrm{C})$ and NL-20 cells inducing Caki-2 cells $(C+N)$, were significant (Tables I-III). Co-culture of the Caki-2 and NL-20 cells resulted in the deregulation of a unique set of 178 genes in the NL-20 cells (Tables I and II, and Fig. 8), when compared to genes deregulated in Caki-2 cells interacting with NL-20 cells $(\mathrm{C}+\mathrm{N})$, as well as ACHN cells induced by NL-20 cells $(\mathrm{A}+\mathrm{N})$ and NL-20 cells induced by ACHN cells $(\mathrm{N}+\mathrm{A})$. At the same time, in the Caki-2 cells, 182 genes were uniquely deregulated if compared to all other interactions $(\mathrm{N}+\mathrm{C}$, $\mathrm{N}+\mathrm{A}$ and $\mathrm{A}+\mathrm{N})$. If the interaction between the NL-20 cells and Caki-2 was analyzed, only 3 genes were deregulated both in the NL-20 cells and Caki-2 cells upon interaction (Fig. 9), out of the 195 deregulated in NL-20 cells and 187 deregulated in Caki-2 cells. The cells before and after interaction differed significantly (co-culture vs. monoculture). If $\mathrm{C}+\mathrm{N}$ was compared with Caki-2 monoculture, 326 genes were deregulated. At the same time, $\mathrm{N}+\mathrm{C}$ co-culture differed by 2,762 genes from NL-20 monoculture (Fig. 8).

Genes deregulated in NL-20 cells from the $\mathrm{N}+\mathrm{C}$ co-culture, compared with NL-2 monoculture were clustered in 2,735 GO 
Table IV. Top analysis-ready molecules in NL-20 cells upon interaction with Caki-2 cells.

\begin{tabular}{|c|c|c|c|}
\hline \multicolumn{2}{|c|}{ Upregulated genes } & \multicolumn{2}{|l|}{ Downregulated genes } \\
\hline Molecules & $\begin{array}{l}\text { Expression } \\
\text { value }\end{array}$ & Molecules & $\begin{array}{l}\text { Expression } \\
\text { value }\end{array}$ \\
\hline $\begin{array}{l}\text { ATP2B1-AS1, } \\
\text { ATP2B1 antisense RNA } 1\end{array}$ & 2.943 & H1FOO, H1 histone family member O, oocyte specific & -3.322 \\
\hline $\begin{array}{l}\text { LINC00899, long intergenic } \\
\text { non-protein coding RNA } 899\end{array}$ & 2.904 & MCEMP1, mast cell expressed membrane protein 1 & -3.241 \\
\hline TMC7, transmembrane channel like 7 & 2.878 & DCDC1, doublecortin domain containing 1 & -3.125 \\
\hline ZNF638, zinc finger protein 638 & 2.740 & LOC101927533, uncharacterized & -3.016 \\
\hline $\begin{array}{l}\text { TBC1D4, TBC1 domain family } \\
\text { member } 4\end{array}$ & 2.715 & SLC37A3, solute carrier family 37 member 3 & -3.002 \\
\hline ZNF765, zinc finger protein 765 & 2.695 & $\begin{array}{l}\text { CATSPERD, cation channel sperm associated auxiliary } \\
\text { subunit delta }\end{array}$ & -2.995 \\
\hline ZNF891, zinc finger protein 891 & 2.563 & MST1P2, macrophage stimulating 1 pseudogene 2 & -2.918 \\
\hline $\begin{array}{l}\text { CCDC178, coiled-coil domain } \\
\text { containing } 178\end{array}$ & 2.560 & VAT1L, vesicle amine transport 1 like & -2.892 \\
\hline $\begin{array}{l}\text { DUSP19, dual specificity } \\
\text { phosphatase } 19\end{array}$ & 2.551 & NR1I3, nuclear receptor subfamily 1 group I member 3 & -2.676 \\
\hline ZNF354B, zinc finger protein 354B & 2.493 & LOC100131372, uncharacterized & -2.576 \\
\hline
\end{tabular}

Table V. Top analysis-ready molecules in NL-20 cells upon interaction with ACHN cells.

\begin{tabular}{|c|c|c|c|}
\hline \multicolumn{2}{|c|}{ Upregulated genes } & \multicolumn{2}{|l|}{ Downregulated genes } \\
\hline Molecules & $\begin{array}{l}\text { Expression } \\
\text { value }\end{array}$ & Molecules & $\begin{array}{l}\text { Expression } \\
\text { value }\end{array}$ \\
\hline $\begin{array}{l}\text { ZC3H12D, zinc finger CCCH-type } \\
\text { containing } 12 \mathrm{D}\end{array}$ & 3.604 & KCNJ12, potassium voltage-gated channel subfamily $\mathbf{J}$ & -4.242 \\
\hline $\begin{array}{l}\text { GPSM } 1, G \text { protein signaling } \\
\text { modulator } 1\end{array}$ & 2.932 & LOC101927814, uncharacterized & -3.187 \\
\hline $\begin{array}{l}\text { PIEZO2, piezo type mechanosensitive } \\
\text { ion channel component } 2\end{array}$ & 2.796 & $\begin{array}{l}\text { GABBR } 1 \text {, gamma-aminobutyric acid type B } \\
\text { receptor subunit } 1\end{array}$ & -2.995 \\
\hline $\begin{array}{l}\text { LINC } 01509 \text {, long intergenic } \\
\text { non-protein coding RNA } 1509\end{array}$ & 2.789 & LOC285484, uncharacterized & -2.979 \\
\hline THAP 2 , THAP domain containing 2 & 2.765 & TSC22D1-AS1, TSC22D1 antisense RNA 1 & -2.857 \\
\hline ZNF90, zinc finger protein 90 & 2.674 & PCSK6, proprotein convertase subtilisin/kexin type 6 & -2.703 \\
\hline $\begin{array}{l}\text { HIST1H1T, histone cluster } 1 \mathrm{H} 1 \\
\text { family member } \mathrm{T}\end{array}$ & 2.663 & COL8A2, collagen type VIII alpha 2 chain & -2.567 \\
\hline $\begin{array}{l}\text { CXCR } 5, \text { C-X-C motif chemokine } \\
\text { receptor } 5\end{array}$ & 2.601 & $\begin{array}{l}\text { AP1S2, adaptor related protein complex } 1 \text { sigma } 2 \\
\text { subunit }\end{array}$ & -2.555 \\
\hline CST6, cystatin E/M & 2.564 & RNF213, ring finger protein 213 & -2.402 \\
\hline $\begin{array}{l}\text { ZCCHC6, zinc finger CCHC-type } \\
\text { containing } 6\end{array}$ & 2.561 & MED1, mediator complex subunit 1 & -2.373 \\
\hline
\end{tabular}

pathways and 40 WikiPathways ( $\mathrm{P} \leq 0.05)$ (Tables I and II). Terpenoid, isoprenoid, retinol and vitamin transport, as well as fatty acid oxidation, histone $\mathrm{H} 3-\mathrm{K} 4$ trimethylation, MAPKKK activity or cellular response to calcium ion (Table I) and apop- 
Table VI. Analysis of the process of ontology deregulated upon the interaction of renal cell carcinoma cells, Caki-2, with normal epithelial NL-20 pleural cells.

\begin{tabular}{ll}
\hline GO Term & P-value \\
\hline $\begin{array}{l}\text { Regulation of epithelial cell proliferation } \\
\text { involved in lung morphogenesis }\end{array}$ & $2.19 \mathrm{E}-04$ \\
Interneuron migration & $3.27 \mathrm{E}-04$ \\
Histone pre-mrna 3'end processing complex & $3.27 \mathrm{E}-04$ \\
Cerebral cortex GABAergic interneuron migration & $3.27 \mathrm{E}-04$ \\
Cerebral cortex GABAergic interneuron & $3.27 \mathrm{E}-04$ \\
development & \\
Interneuron migration from the subpallium & $4.56 \mathrm{E}-04$ \\
to the cortex & \\
Cerebral cortex GABAergic interneuron & $9.68 \mathrm{E}-04$ \\
differentiation & \\
Substrate-independent telencephalic tangential & 0.00118 \\
interneuron migration & \\
Substrate-independent telencephalic tangential & 0.00118 \\
migration & \\
Clathrin-sculpted vesicle & \\
GABAergic neuron differentiation & 0.001411 \\
Telencephalon cell migration & 0.001411 \\
Learning & 0.00212 \\
Forebrain cell migration & 0.002363 \\
Telencephalon development & 0.002476 \\
Neural nucleus development & 0.002633 \\
Transcription, DNA-templated & 0.003443 \\
Nucleic acid-templated transcription & 0.003965 \\
RNA biosynthetic process & 0.004027 \\
\hline & 0.004046 \\
& 0.004227 \\
\hline
\end{tabular}

First 20 annotations for Caki-2 cells are selected.

Table VII. Analysis of the biological pathway (WikiPathways) deregulation upon the interaction of Caki- 2 renal cell carcinoma cells and normal epithelial NL-20 pleural cells.

\begin{tabular}{lcc}
\hline Pathway name & Pathway no. & P-value \\
\hline $\begin{array}{l}\text { Extrinsic pathway for } \\
\text { apoptosis }\end{array}$ & WP181477023 & 0.049741678 \\
$\begin{array}{l}\text { Transcriptional regulation } \\
\text { of white adipocyte }\end{array}$ & WP2751 76992 & 0.02918972 \\
differentiation & & \\
$\begin{array}{l}\text { RNA Polymerase I, RNA } \\
\text { Polymerase III, and }\end{array}$ & WP1905 77034 & 0.03143341 \\
$\begin{array}{l}\text { mitochondrial transcription } \\
\text { Signal amplification }\end{array}$ & & \\
$\begin{array}{l}\text { GABA synthesis, release, } \\
\text { reuptake and degradation }\end{array}$ & WP2685 76885 & 0.053199083 \\
\hline
\end{tabular}

Pathways deregulated in Caki-2 cells are shown.
Table VIII. Analysis of the process of ontology deregulated upon the interaction of ACHN renal cell carcinoma cells with normal epithelial NL-20 pleural cells.

\begin{tabular}{ll} 
GO Term & P-value \\
\hline Voltage-gated cation channel activity & $9.48 \mathrm{E}-05$ \\
System process & $1.27 \mathrm{E}-04$ \\
Detection of chemical stimulus involved & $2.29 \mathrm{E}-04$ \\
in sensory perception &
\end{tabular}

ory perception

Oculomotor nerve formation

2.89E-04

Oculomotor nerve morphogenesis

2.89E-04

Detection of stimulus involved in

2.93E-04

sensory perception

Sensory perception of chemical stimulus

3.27E-04

Voltage-gated channel activity

5.11E-04

Voltage-gated ion channel activity

5.11E-04

Cation channel complex

5.34E-04

Substrate-specific channel activity

5.51E-04

Bitter taste receptor activity

$5.67 \mathrm{E}-04$

Cation channel activity

$6.05 \mathrm{E}-04$

Detection of chemical stimulus

6.61E-04

Digestive tract development

7.93E-04

Extracellular matrix component

8.39E-04

Stereocilium membrane

8.59E-04

Basement membrane

9.29E-04

Passive transmembrane transporter

9.45E-04 activity

Channel activity

9.45E-04
Table IX. Analysis of biological pathway (WikiPathways) deregulation upon interaction of $\mathrm{ACHN}$ renal cell carcinoma cells and normal epithelial NL-20 pleural cells.

\begin{tabular}{|c|c|c|}
\hline Pathway name & Pathway no. & P-value \\
\hline $\begin{array}{l}\text { Translocation of GLUT4 to } \\
\text { the plasma membrane }\end{array}$ & WP2777 77058 & 0.054280035 \\
\hline Potassium channels & WP2669 76853 & 0.006594973 \\
\hline $\begin{array}{l}\text { Assembly of collagen } \\
\text { fibrils and other } \\
\text { multimeric structures }\end{array}$ & WP2798 77089 & 0.016301567 \\
\hline $\begin{array}{l}\text { Transcriptional } \\
\text { regulation of pluripotent } \\
\text { stem cells }\end{array}$ & WP2821 76135 & 0.03988874 \\
\hline $\begin{array}{l}\text { Regulation of water } \\
\text { balance by renal } \\
\text { aquaporins }\end{array}$ & WP2662 76842 & 0.00920225 \\
\hline
\end{tabular}

Pathways deregulated in ACHN cells are shown. 


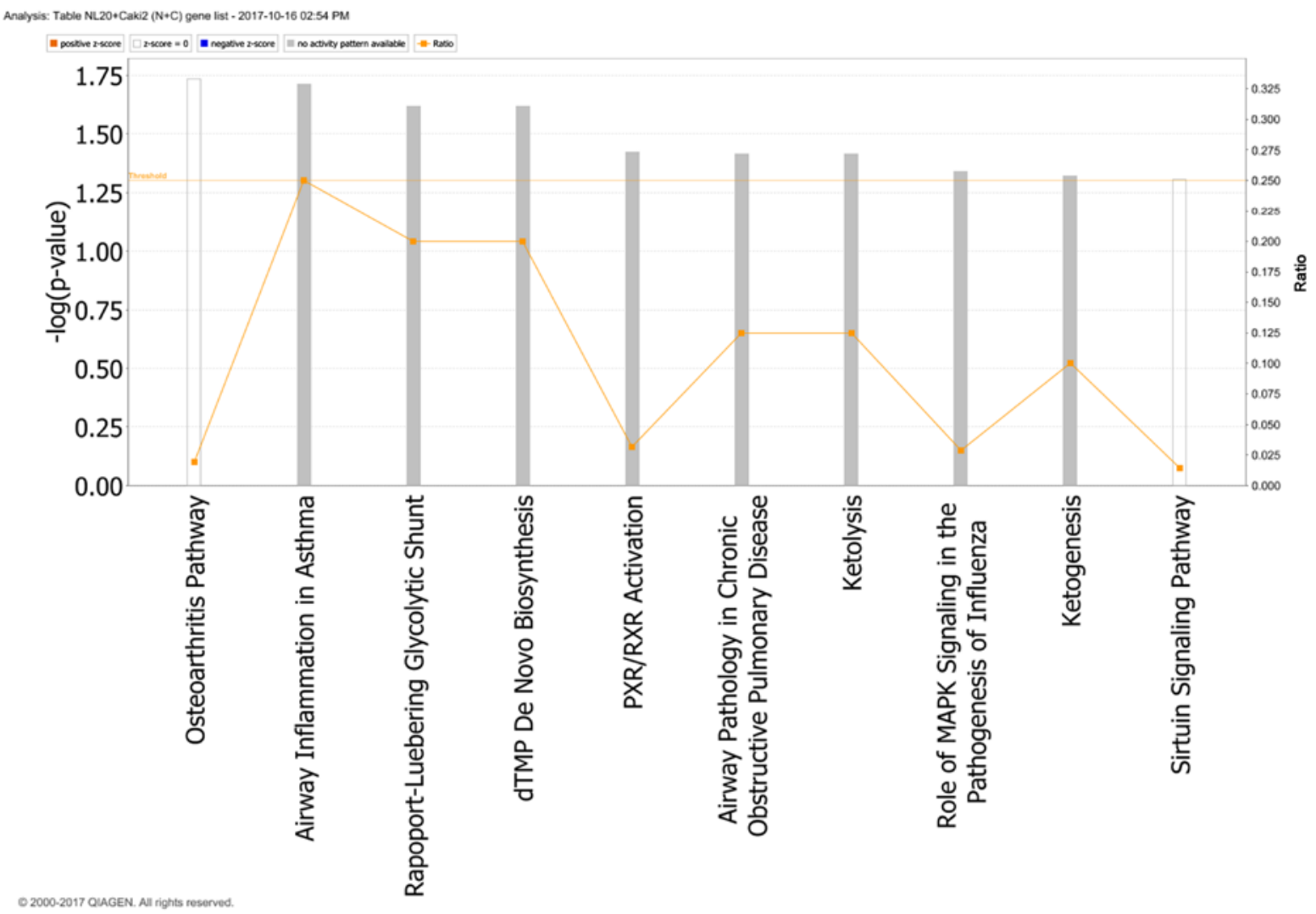

Figure 10. Top canonical pathways deregulated upwards in NL-20 cells induced by Caki-2 cells defined by Ingenuity Pathway Analysis.

totic signaling (Table II) were induced in metastatic target organ cells upon interaction with cancer cells. In induced cells, glycosylation endproduct receptor signaling with syndecan interactions (potentially with multiple ligands including fibroblast growth factors (FGFs), vascular endothelial growth factor (VEGF), transforming growth factor- $\beta$ (TGF- $\beta$ ), fibronectin or antithrombin-1) were deregulated, as well as downstream effects of PIP2 hydrolysis (by G protein-coupled receptors listed above). The transcription factors, peroxisome proliferator-activated receptor $\gamma(\operatorname{PPAR} \gamma)$, and CCAAT/enhancer binding protein $(\mathrm{C} / \mathrm{EBP})$, the transcriptional cascades of white adipocyte differentiation were also deregulated. Prolactin receptor signaling with the major downstream signaling modules JAK/STAT, RAS/RAF/MAPK, PI3-Kinase/AKT and RAC was also deregulated in the metastatic target organ normal cells (pleural epithelial cells) (Table II).

In particular, in the NL-20 cells, upon interaction with Caki-2 cells, the top canonical pathways activated were those of osteoarthritis $(\mathrm{P}=1.84 \mathrm{E}-02)$, airway inflammation $(\mathrm{P}=1.94 \mathrm{E}$ 02), Rapoport-Luebering glycolytic shunt ( $\mathrm{P}=2.42 \mathrm{E}-02)$, dTMP de novo biosynthesis $(\mathrm{P}=2.42 \mathrm{E}-02)$ and $\mathrm{PXR} / \mathrm{RXR}$ activation $(\mathrm{P}=3.80 \mathrm{E}-02)$ pathways (Fig. 10) with zinc finger proteins, long intergenic and non-protein coding RNA and antisense RNA activation (Table IV). IPA analysis also revealed that networks deregulated upon interaction were responsible for hematological system development and function, immunological diseases, lymphoid tissue structure and development (score $=35$ ), cellto-cell signaling and interaction, connective tissue disorders, developmental disorders ( organismal injury and abnormalities (score $=23$ ), as well as cellular growth and proliferation (score $=21$ ). Cell morphology, lipid metabolism and molecular transport (Fig. 11), cell-tocell signaling and interaction, connective tissue disorder and developmental disorder (Fig. 12) as well a cell-to-cell communication (Fig. 13) networks analysis revealed that induced NL-20 cell-cell communication was mediated by VEGF, protein phosphatase, $\mathrm{Mg}^{2+} / \mathrm{Mn}^{2+}$ dependent $1 \mathrm{~N}$ (PPM1N), IL-15, IL-26, insulin like growth factor binding protein 1 (IGFB1), complement factor B (CFB), phospholipase A1 member A (PLA1A), ovostatin 2 (OVOS2), serpin family D member 1 (SERPIND1), but tumor necrosis factor (TNF), IL-1, IL-6, kidney-associated antigen 1 (KAAG1) and mucin 6 (MUC6) signaling was downregulated.

At the same time genes deregulated in Caki- 2 cells from $\mathrm{C}+\mathrm{N}$ co-culture, compared with Caki-2 monoculture were clustered in and 276 GO pathways and 17 WikiPathways $(\mathrm{P} \leq 0.05)$ (Tables V and VI). In the cancer cells, histone pre-mRNA 3' end processing complex, nucleic acid-templated transcription, RNA biosynthetic processes along with morphogenesis and migration were deregulated (Table VI). At the same time, apoptotic signaling, RNA polymerase I, RNA polymerase III, and mitochondrial transcription and GABA synthesis, release, reuptake and degradation (Table VI) were significantly altered. Therefore, it seems that normal cell function is more influenced upon first cancer cell interaction, than is the physiology of the cancer cell.

Gene expression is deregulated upon the interaction of metastatic RCC tumor cells with normal pleural cells. Co-culture of the ACHN and NL-20 cells resulted in the deregulation of 


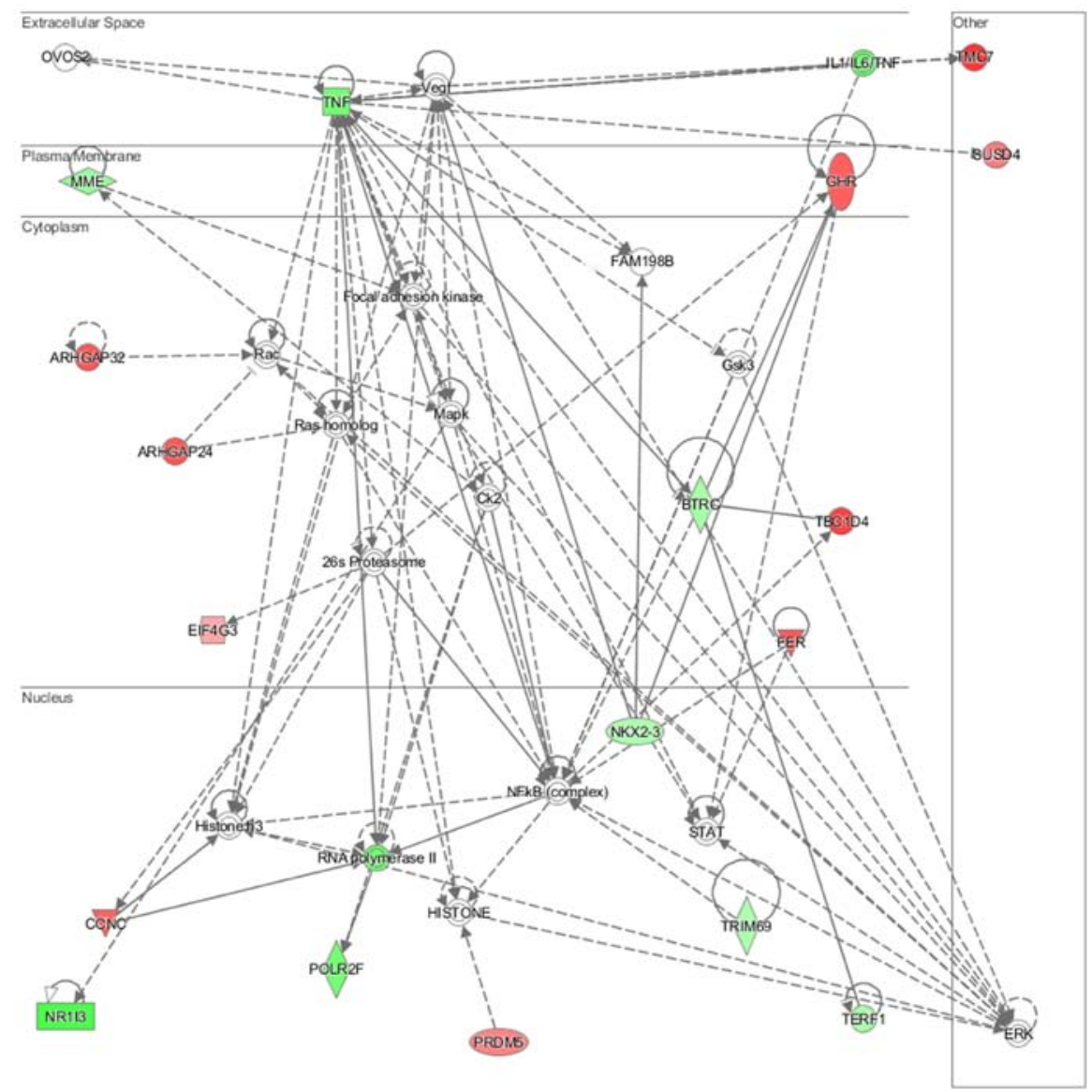

Figure 11. Top deregulated networks in NL-20 cells: Hematological system development and function, immunological disease, lymphoid tissue structure and development network induced by Caki-2 cells defined by Ingenuity Pathway Analysis.

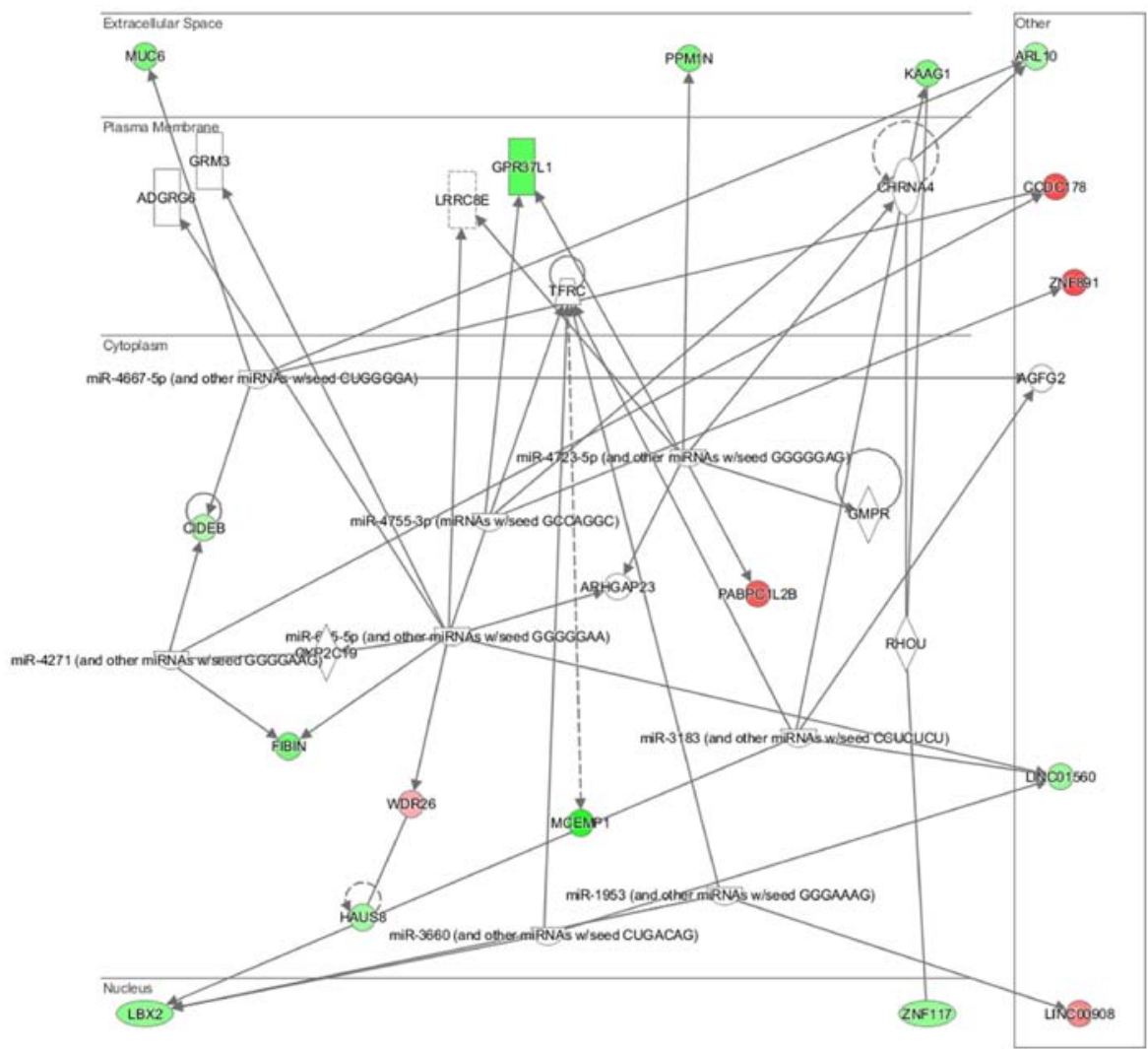

Figure 12. Significantly deregulated networks in NL-20 cells: Cell-to-cell signaling and interaction, connective tissue disorder and developmental disorder induced by Caki-2 cells defined by Ingenuity Pathway Analysis. 


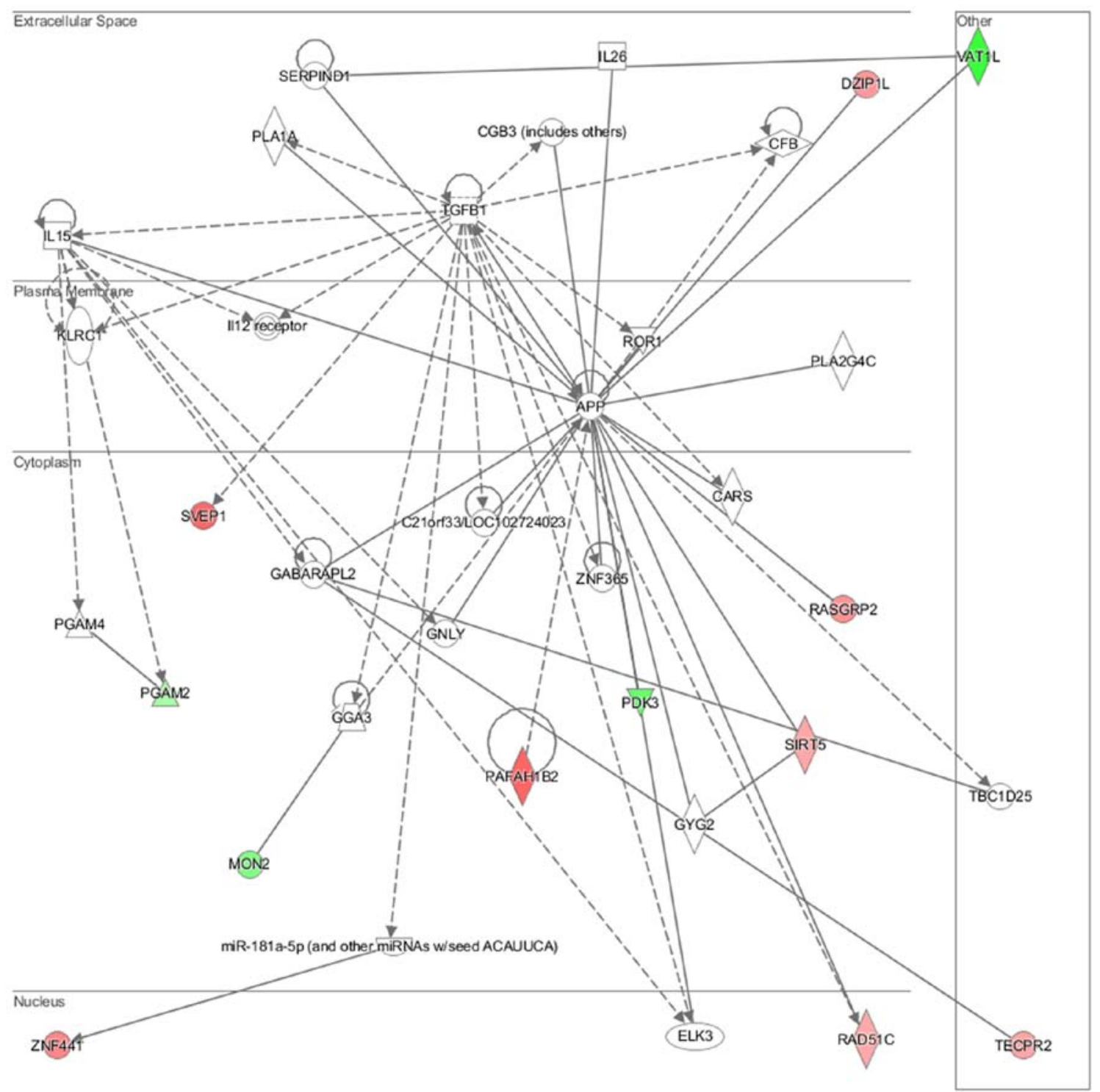

Figure 13. Significantly deregulated networks in NL-20 cells: Cell-cell interaction induced by Caki-2 cells defined by Ingenuity Pathway Analysis.

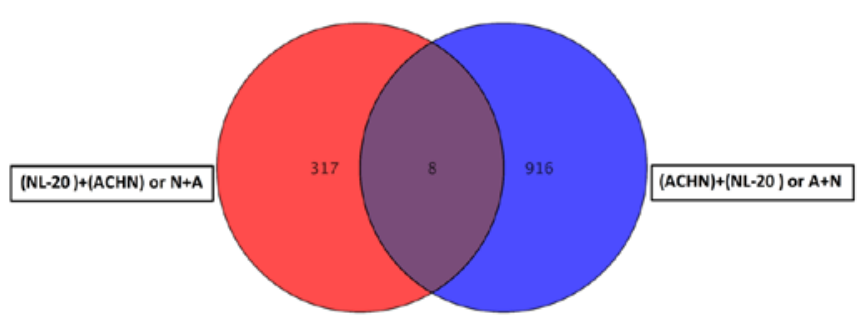

Figure 14. Differentially expressed genes between NL-20 cells vs. NL-20 + ACHN co-culture and ACHN cells vs. ACHN + NL-20 co-culture was obtained by GeneSpring GX 13.0 software.

unique set of 314 genes in NL-20 cells (Table I and Fig. 8), when compared to genes deregulated in ACHN cells interacting with NL-20 cells $(\mathrm{A}+\mathrm{N})$, as well as in Caki-2 cells induced by NL-20 cells $(\mathrm{C}+\mathrm{N})$ and NL-20 cells induced by Caki-2 cells $(\mathrm{N}+\mathrm{C})$. At the same time, in ACHN cells, 902 genes were uniquely deregulated if compered to all other interactions $(\mathrm{N}+\mathrm{A}, \mathrm{N}+\mathrm{C}$ and $\mathrm{C}+\mathrm{N})$. If the interaction between the NL-20 cells and ACHN cells was analyzed, only 8 genes were deregulated both in the NL-20 cells and in ACHN cells upon interaction (Fig. 14), out of the 325 genes deregulated in the NL-20 cells and 924 genes deregulated in the ACHN cells. If $\mathrm{A}+\mathrm{N}$ was compared with ACHN monoculture 25,735 genes were deregulated. At the same time, $\mathrm{N}+\mathrm{A}$ co-culture differed by 27,707 genes from the NL-20 monoculture (Table VIII).

Genes deregulated in the NL-20 cells from $\mathrm{N}+\mathrm{A}$ co-culture, compared with NL-20 monoculture were clustered in 544 GO pathways and 69 WikiPathways $(\mathrm{P} \leq 0.05)$ (Tables I and III). In particular, in NL-20 cells upon interaction with ACHN cells, the top canonical networks deregulated were actin nucleation by ARP-WASP complex ( $\mathrm{P}=1.16 \mathrm{E}-03)$, ATM signaling $(\mathrm{P}=1.24 \mathrm{E}-03)$, Cdc42 signaling $(\mathrm{P}=4.29 \mathrm{E}-03)$, regulation of actin-based motility by Rho (P=5.54E-03) and Reelin signaling in neurons ( $\mathrm{P}=7.03 \mathrm{E}-03)$ (Fig. 15). Cell morphology, lipid metabolism and molecular transport (Fig. 16), cell death and survival, embryonic development, nervous system development and function (Fig. 17), cell signaling and interaction (Fig. 18) network analysis revealed that the ACHN-induced NL-20 cell-cell communication was mediated by IL-1, 


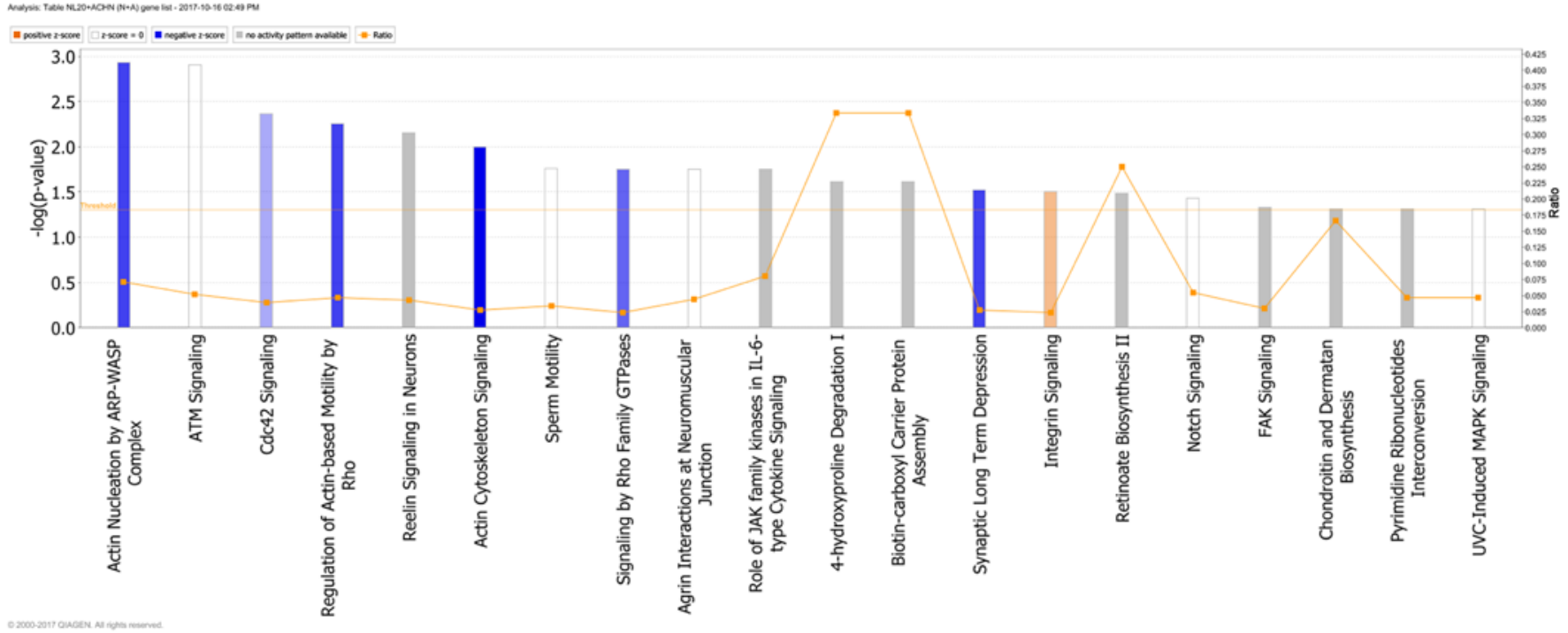

Figure 15. Top canonical pathways deregulated up in NL-20 cells induced by ACHN cells defined by Ingenuity Pathway Analysis.
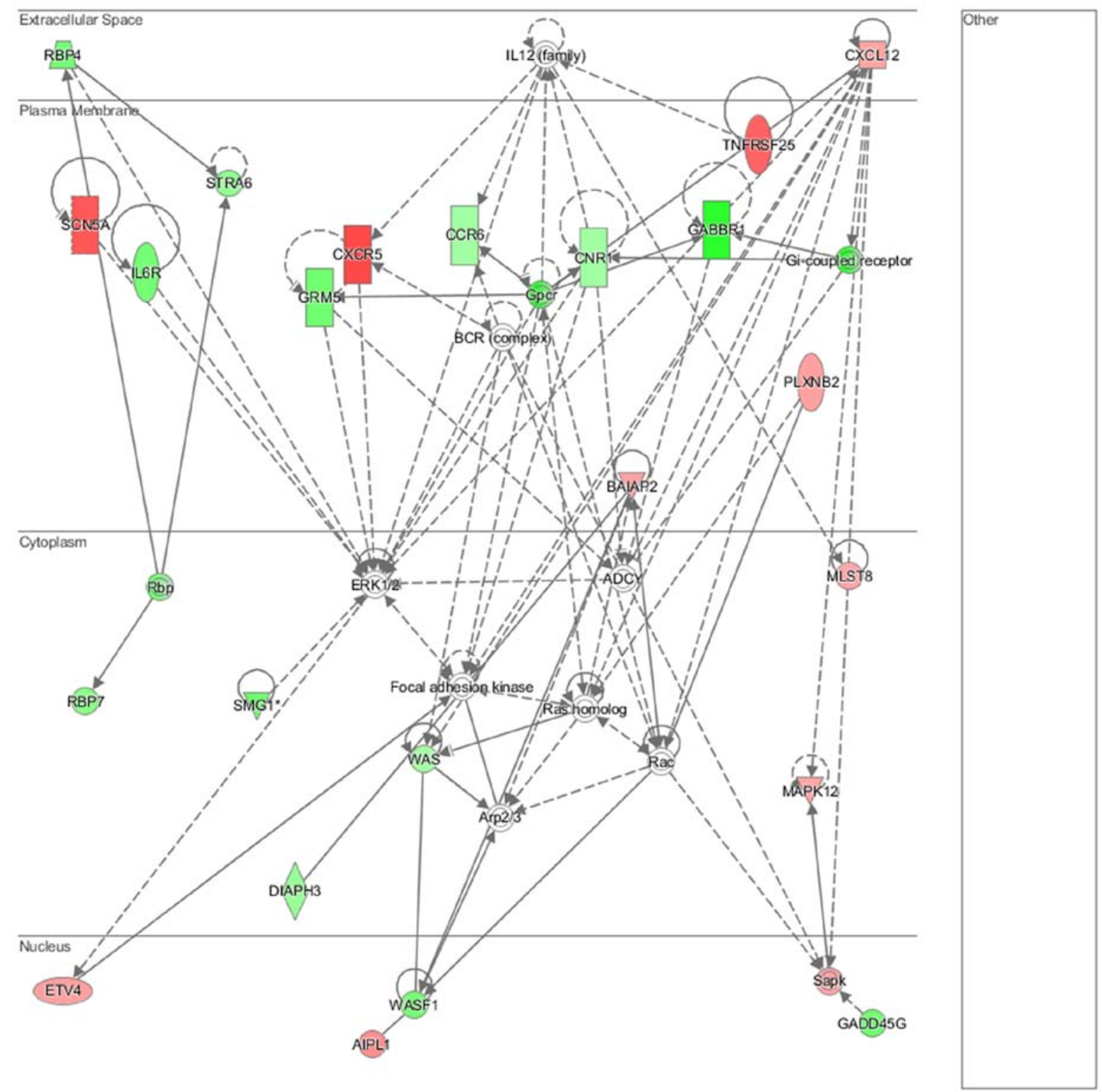

Figure 16. Top deregulated networks in NL-20 cells: Cell morphology, lipid metabolism and molecular transport networks induced by ACHN cells defined by Ingenuity Pathway Analysis. 


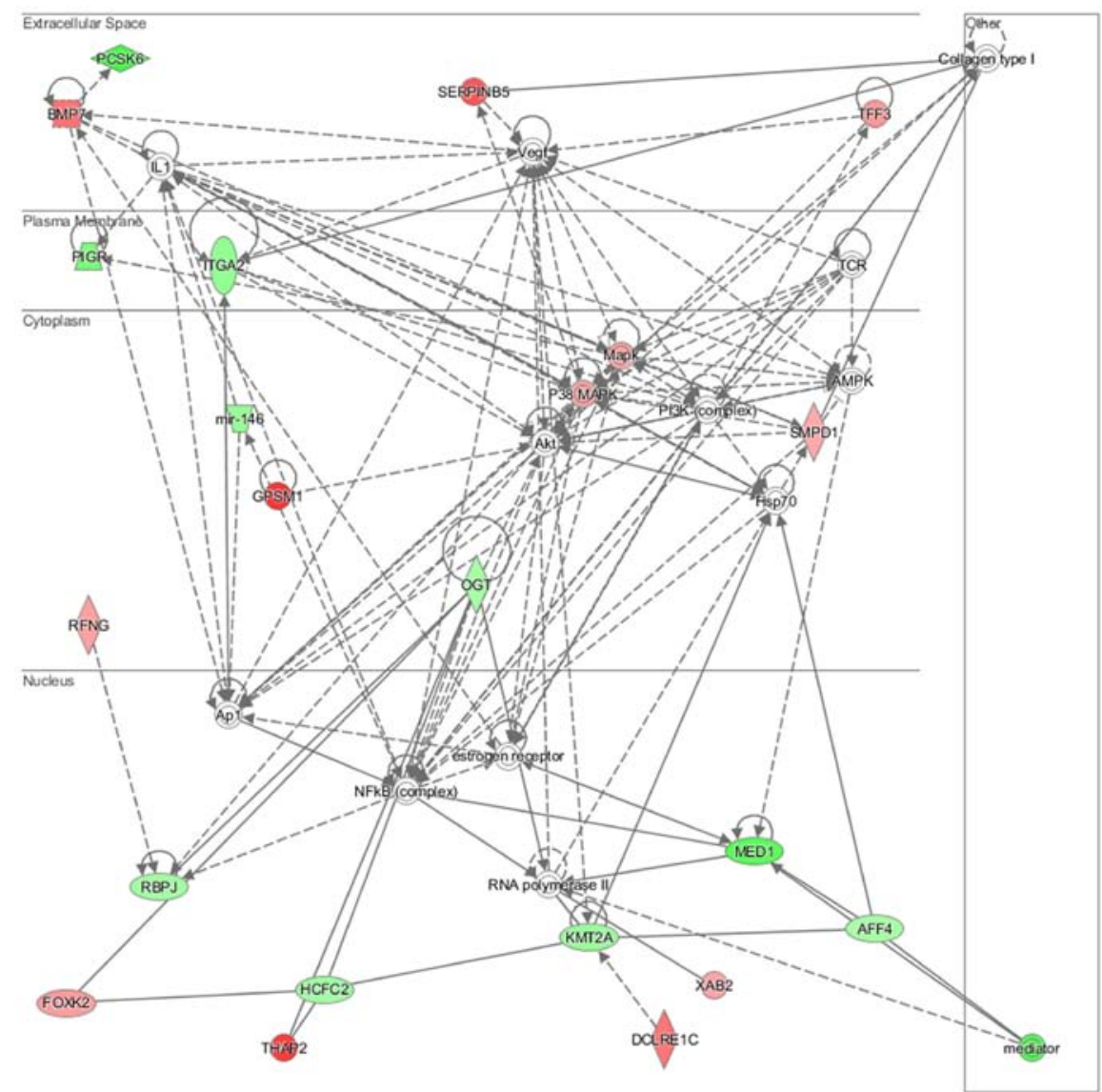

Figure 17. Deregulated networks in NL-20 cells: Cell-to-cell signaling and interaction, connective tissue disorder, developmental disorder networks induced by ACHN cells defined by Ingenuity Pathway Analysis.

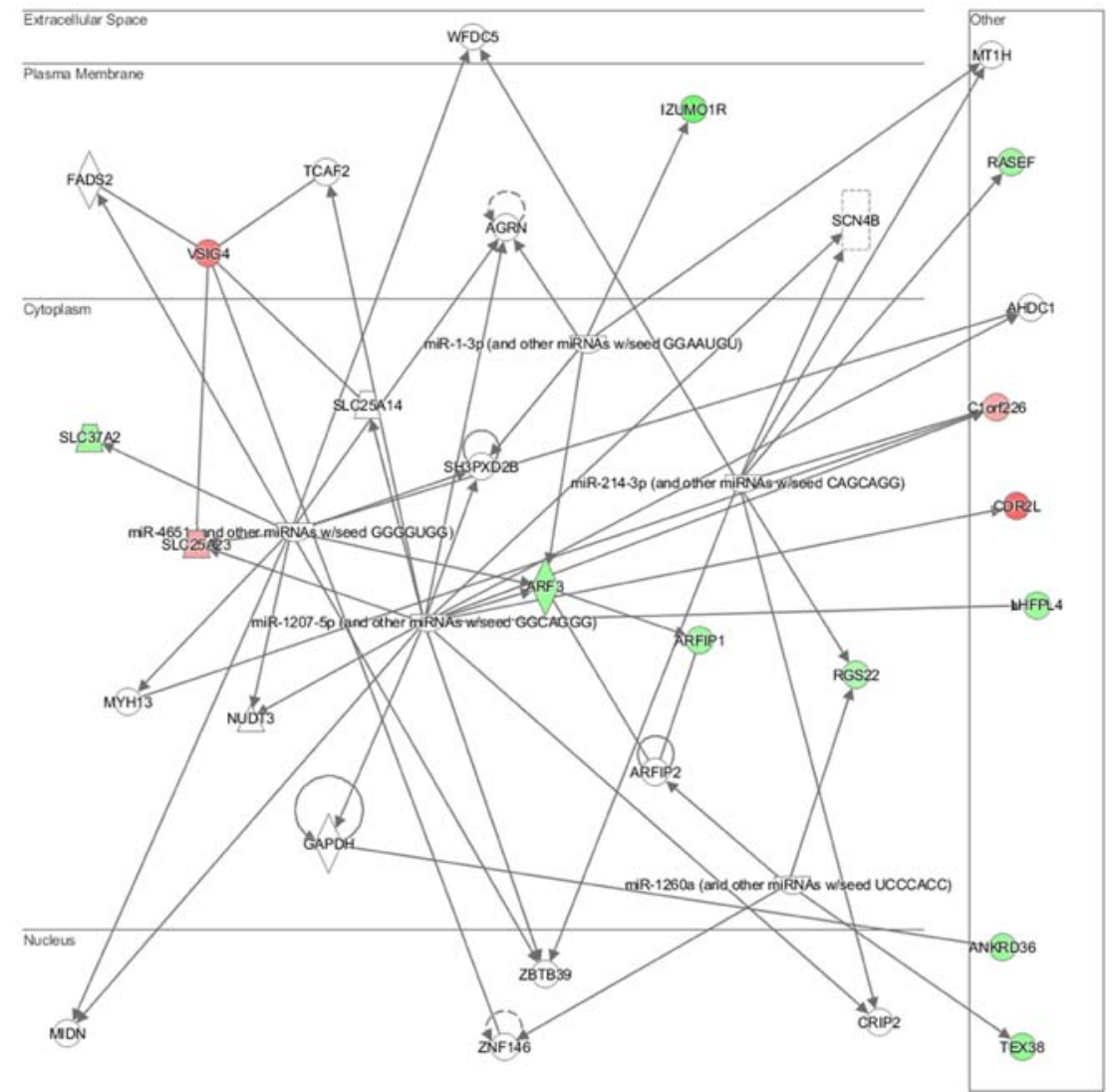

Figure 18. Deregulated networks in NL-20 cells: Cell-cell communication networks induced by ACHN cells defined by Ingenuity Pathway Analysis. 


\section{IL-6 normox}

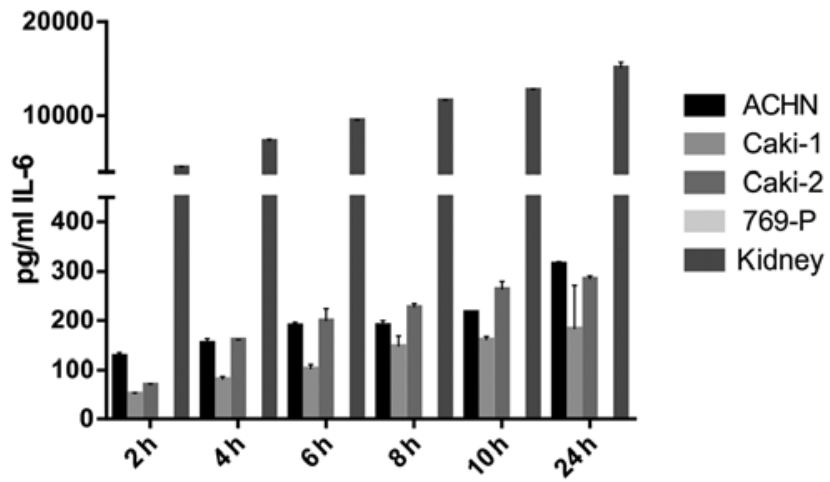

\section{IL-6 hypox}

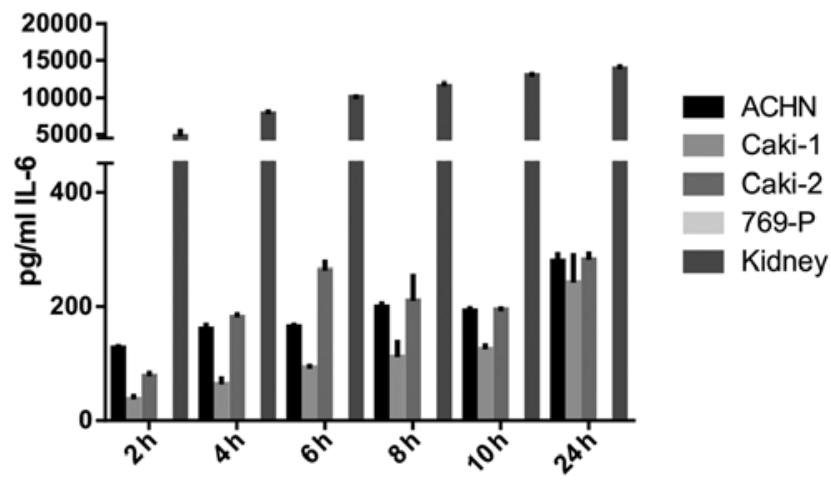

Figure 19. Interleukin-6 (IL-6) secretion by RCC cancer cell lines (ACHN, Caki-1, Caki-2, 769-P), and normal renal cells (RPTECs, kidney) under normoxie (upper panel; normox) and hypoxic (lower panel; hypox) conditions.
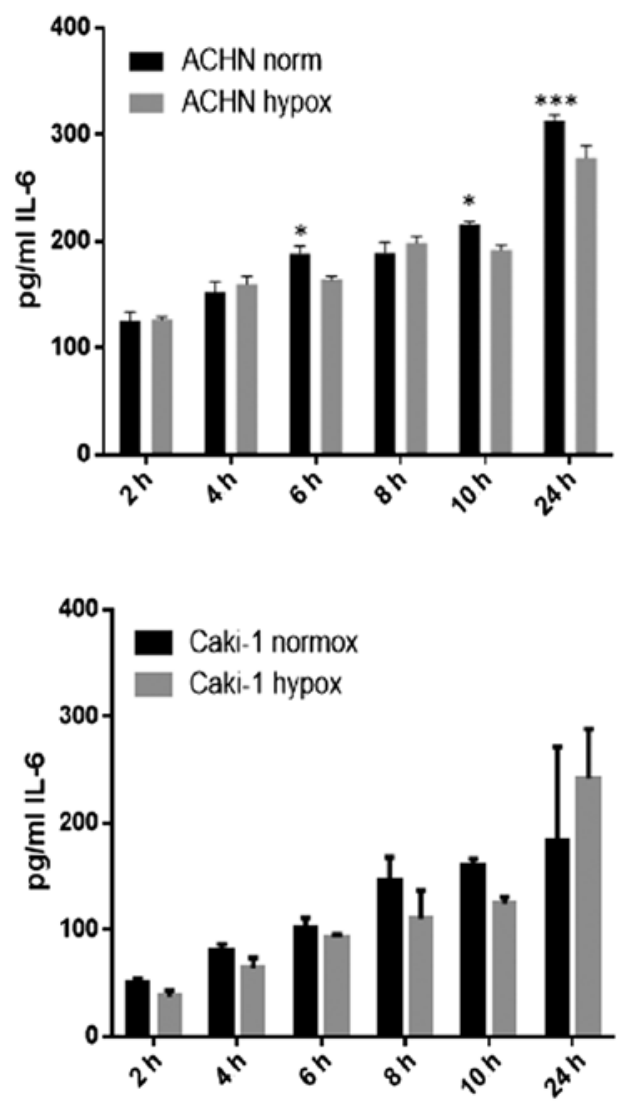
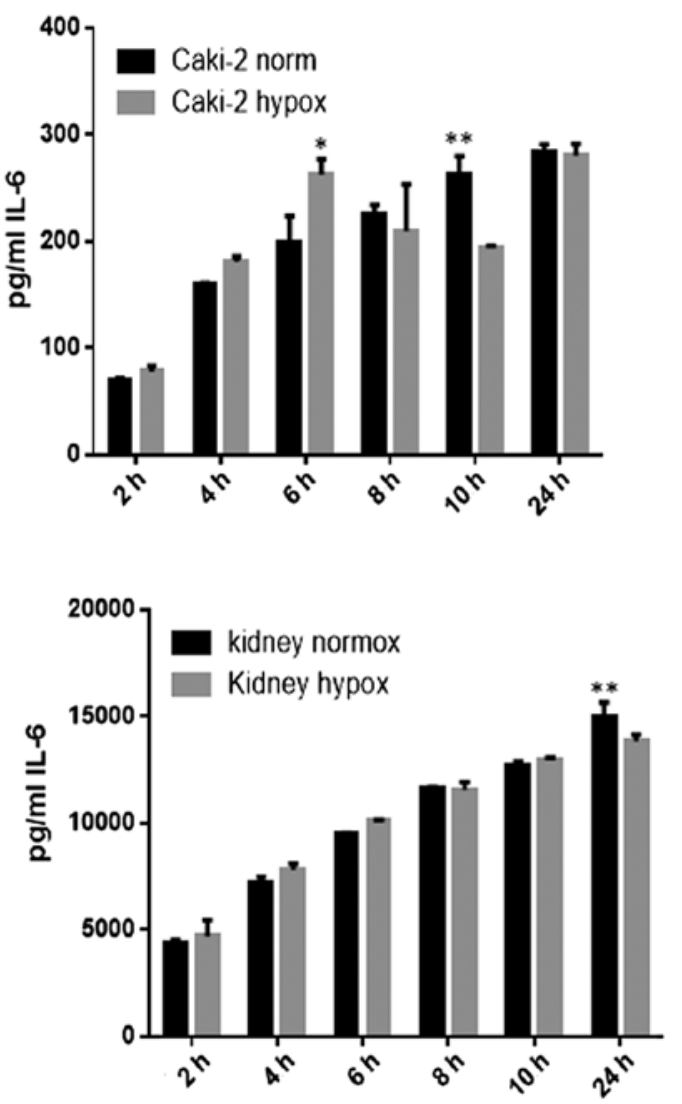

Figure 20. Time-dependent interleukin-6 (IL-6) secretion by RCC cancer cell lines (ACHN, Caki-1, Caki-2) and normal renal cells (RPTECs, kidney) under normoxic (normox) and hypoxic (hypox) conditions. ${ }^{* * *} \mathrm{P}<0.001,{ }^{* * *} \mathrm{P}<0.01$ and ${ }^{*} \mathrm{P}<0.05$.

IL-12, VEGF, putative protease inhibitor WAP1 (WFDC5), while C-X-C motif chemokine ligand 12 (CXCL12), trefoil factor 3 (TFF3), serpin family B member 5 (SERPINB5), bone morphogenetic protein 7 (BMP7) signaling was upregulated.

IPA analysis also revealed that networks deregulated upon interaction were responsible for cell morphology, lipid metabolism, molecular transport (score $=42$ ), cell death and survival, embryonic development, nervous system development and function (score $=35$ ), cancer, organismal injury and abnormalities, (score $=32$ ) and connective tissue disorders (score $=30$ ). Upon interaction in the NL-20 cells, IL-6, opioid and DAG and
IP3 signaling were deregulated with mothers against decapentaplegic homologs (SMAD)2-SMAD3-SMAD4 deregulated (Table III), C-X-C motif chemokine receptor 5 (CXCR5) and zinc finger proteins upregulated (Table VII).

IL- 6 was secreted by RCC cancer cell lines (ACHN, Caki-1, Caki-2, 769-P), as well as normal renal cells (RPTEC) (Fig. 19), both under normoxic and hypoxic conditions, with a trend towards a higher expression in $21 \% \mathrm{O}_{2}$ (Fig. 20). On the contrary, under the hypoxic $\left(1 \% \mathrm{O}_{2}\right)$ condition, the RCC cell lines secreted significantly more IL-6sR than under normoxic conditions (Figs. 21 and 22). The secretion of IL-6sR by cells 

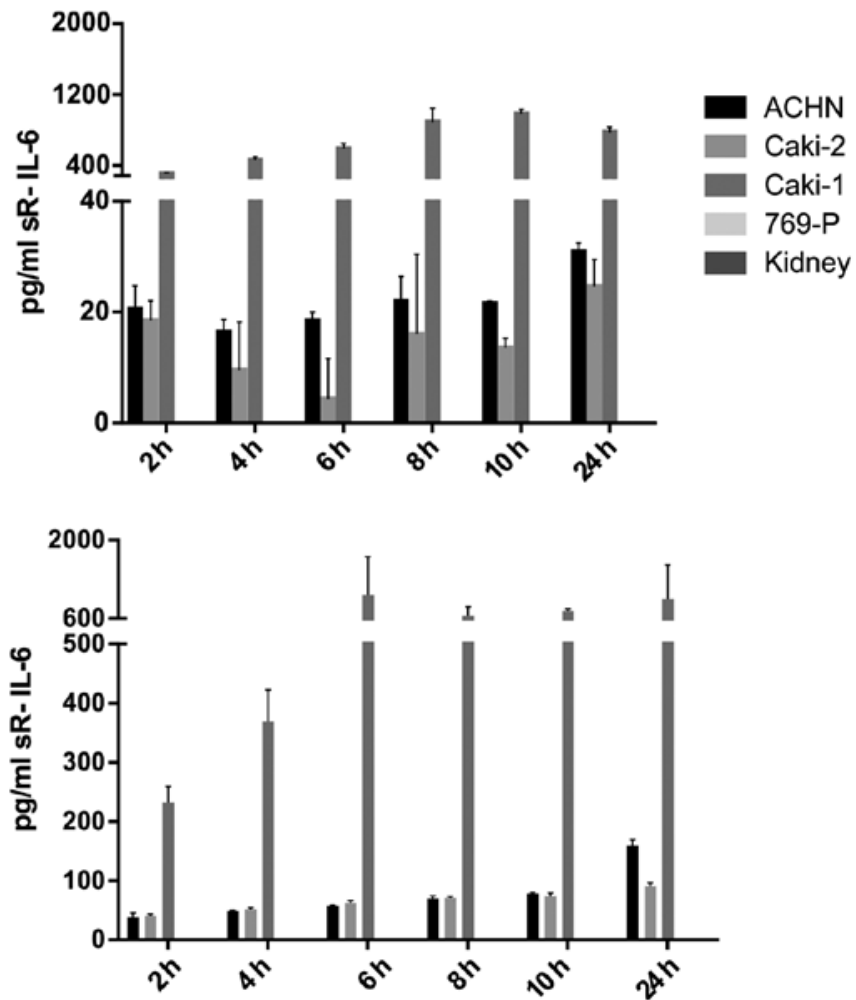

Figure 21. Interleukin-6 (IL-6) soluble receptor (sR-IL-6) secretion by RCC cancer cell lines (ACHN, Caki-1, Caki-2, 769-P), and normal renal cells (RPTECs, kidney) under normoxic (upper panel) and hypoxic (lower panel) conditions.
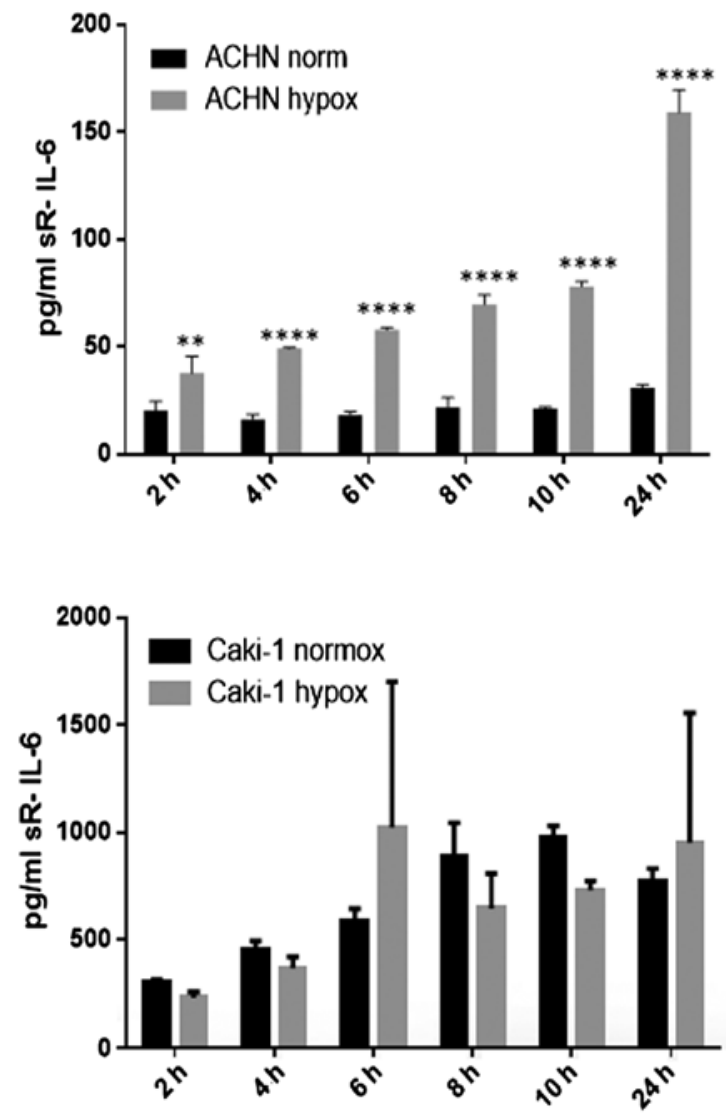

Figure 22. Time-dependent interleukin-6 (IL-6) soluble receptor(sR-IL-6) secretion by RCC cancer cell lines (ACHN and Caki-1) under normoxic (normox) and hypoxic (hypox) conditions. ${ }^{* * * *} \mathrm{P}<0.0001$ and ${ }^{* *} \mathrm{P}<0.01$. derived from normal renal cells was below the detection limit (Fig. 21).

Genes deregulated in ACHN cells from A + N co-culture, compared with ACHN monoculture were clustered in $397 \mathrm{GO}$ pathways and 67 WikiPathways in the ACHN cells $(\mathrm{P} \leq 0.05)$. Multiple channels activity, extracellular matrix component and basement membrane signaling are deregulated along with transcriptional regulation of pluripotent stem cells (Tables VIII and IX). The inhibition of complex IL-6/IL-6sR signaling by gp130 decreased the proliferation of induced RCC cell lines. Alternative signal transduction pathways other than gp130/STAT3 are responsible for this phenomenon as STAT3 and gp130 were not overexpressed in RCC cells and STAT3 was not phosphorylated upon CM induction, although IL-6R (membrane receptor) was expressed by the cells (data not shown).

\section{Discussion}

From the number of deregulated pathways reported above, we concluded that there was a larger influence of cancer cells on normal cells than vice versa in RCC metastasis development. Our analysis of cDNA array data indicated that crosstalk between healthy NL-20 cells and RCC cells mostly results in the deregulation of cell-cell signaling, mitosis and cell cycling, cell motility pathways, as well as intracellular transport and metabolism, including the regulation of RNA biosynthesis (Tables I-IX). Our findings are in accordance with those of other high throughput whole-genome reports which indicate alterations in genes controlling RCC development $(25,26)$.

Genes deregulated in pleural cells following interaction with RCC cells were found to be involved in multiple metabolic pathways, including terpenoid, isoprenoid, retinol and vitamin transport, as well as fatty acid oxidation, Rapoport-Luebering glycolytic shunt and dTMP de novo biosynthesis (Table I). These pathways may be considered as targets for cancer-selective therapies, including the development of small molecules targeting metabolic enzymes, metabolic modulators or pharmacologic activators that could be combined with cytotoxic therapies to increase apoptosis induction in RCC cells. In fact our study supports the hypothesis that metastatic RCC could potentially become the disease of interest for metabolic oncology research (27). Terpenoids currently used in humans constitute 6 major drug classes: steroids, tocopherols, taxanes, artemisinins, ingenanes and cannabinoids, all of which are of potential interest in oncology (28). As terpenoids are useful in the prevention and therapy of several diseases, including cancer, and also have anti-spasmodic, antimicrobial, anti-parasitic, anti-fungal, anti-viral, anti-allergenic, anti-hyperglycemic, anti-inflammatory, and immunomodulatory properties, the deregulation of their transport into the cells may significantly impact RCC treatment, but may also represent a novel therapeutic target. Currently, over 40,000 individual compounds have been described in this group of molecules and many may be potentially important for RCC treatment (29). At the same time, natural isoprenoids in cancer cells are generated by the mevalonate (MEV) cascade that is commonly deregulated upon cell transformation. In cancer cells, glucose, glutamine and acetate are substrates for anabolic MEV pathway. Moreover, 3-hydroxy-3-methylglutaryl-CoA reduc- 
tase (HMGCR) that is the rate-limiting enzyme of MAV, is now considered a metabolic oncogene (30). Furthermore, the Rapoport-Luebering glycolytic shunt generates and dephosphorylates 2,3-diphospho-D-glycerate (2,3-BPG). In cells, 2,3-BPG functions as a biochemical link between the turnover of phosphorylated inositol derivatives and glycolysis. It is a regulator of type I inositol-1,4,5-trisphosphate 5-phosphatase and phosphatidylinositol-3,4,5-trisphosphate 5-phosphatase 1 (SHIP). In turn, SHIP1, following stimulation by different cytokine receptors, interacts with activated Shc protein, and promotes its binding to Grb2/Sos1 complexes. The membrane recruitment of SHIP1 serves as the inhibitory signals modulating phosphatidylinositol 3-kinase (PI3K)-dependent signaling pathways (31). The PI3K/AKT pathway is often mutated and most often highly activated in RCC and it is a promising drug target. In fact PI3K pathway inhibitors of the rapalog family are approved for use in RCC. On the tissue level, the activation of the PI3K/AKT pathway, subsequently increasing the expression levels of matrix metalloproteinase (MMP)-13 and urokinase plasminogen activator (uPA), promotes the invasion and migration of RCC cells $(32,33)$.

We also demonstrated that histone $\mathrm{H} 3-\mathrm{K} 4$ trimethylation, MAPKKK activity or cellular response to calcium ion (Table I), as well as apoptotic signaling (Table II) were deregulated in metastatic target organ cells upon interaction with RCC cancer cells. It is well known that abnormal MAPK pathway signaling is often involved in the progression of cancer, since MAPKs are involved in cell migration and invasion, since these kinases regulate the expression and activation of focal adhesion kinase (FAK) and MMPs (34). In accordance with our results, it has also been reported that RCC histone $\mathrm{H} 3$ lysine 4-trimethyl (H3K4me3) levels inversely correlate with Fuhrman grading, pT stage, lymph node involvement and distant metastasis and that global histone modifications are possibly potential RCC prognosis markers (35). Our analysis also revealed that the interaction with RCC cells resulted in induced glycosylation end product receptor signaling and syndecan interactions (Table II). In humans, syndecan-1 (CD138) is a cell-surface heparan sulfate proteoglycan expressed on most epithelial cells, and a decreased CD138 expression has previously been shown to be associated with increased invasive and metastatic potential in cancers. In terms of function syndecan-1 affects mesenchymal tumor cell proliferation, adhesion, migration and motility (36). Syndecan-1 exerts its functions via the heparan sulfate chains, that bind multiple receptors, including FGFs, VRGF, TGF- $\beta$, Wnt, HGF fibronectin or antithrombin-1, all known to play significant roles in RCC development and progression $(37,38)$. Concurrently, prolactin receptor signaling via JAK/STAT, RAS/RAF/MAPK, PI3-Kinase/AKT and RAC is also deregulated in pleural epithelial cells upon RCC cell interaction, while JAK/STAT3 signaling, AMPK and PPAR $\alpha$, are putative therapeutic targets in renal cell carcinoma (39-41).

Indeed, the deregulation in signaling was also observed in NL-20 cells co-cultured with the RCC metastatic cell line (Table III and Figs. 15-18). Primarily, the IL-6 signaling pathway was deregulated in NL-20 cells. It has been shown that in patients with RCC, the level of IL-6, inter alia, is increased (42) and RCC primary cultures secrete elevated levels of IL-6 as well (43). These data suggest the involvement of this cytokine in the progression of RCC. Moreover, in men with prostate cancer which has metastasized to the bone, plasma IL-6 levels and its soluble receptor (IL-6sR) levels are extremely high (44), what indicates their role in metastasis. IL-6sR is released from membrane-bound receptor IL-6 (IL-6R) by ectodomain shedding (45) by the enzymes which belong to the A disintegrin and metalloproteinase (ADAM) gene family of metalloproteases, ADAM-17 and ADAM-10 (46). ADAM17 expression has been shown to be upregulated in several types of cancer, including breast cancer, head and neck cancer and prostate cancer, hepatocellular cancer and non-small cell lung cancer (NSCLC), which may also lead to the increased generation of sIL-6R and activation of IL-6 trans-signaling (47). In ccRCC, the loss of TIMP-3, which is the inhibitor of the actions of ADAM-10 and ADAM-17, expression is observed (48). These data suggest the great potential of ccRCC for releasing of IL-6sR. Thus, it can be hypothesized that this complex, IL-6sR/IL6, may be a mediator in the metastasis of ccRCC. It was previously shown that signaling via the sIL-6R is often observed in chronic inflammatory disorders, such as rheumatoid arthritis, Crohn's disease and colon cancer (49,50). IL-6 trans-signaling promotes pro-inflammatory pathways via the inhibition of lamina propria T-cell apoptosis, the stimulation of enhanced IEC proliferation and maintenance of the TH17 phenotype in inflamed tissues. Endothelial cells upregulated the expression of gp130, downregulated the expression of the membrane-bound IL-6R and were targeted by the IL-6/IL-6sR complex, which led to proliferation, inhibition of apoptosis and enhanced colonic carcinogenesis (51). Furthermore, the IL-6/sIL-6R complex is commonly upregulated under pathophysiological situations (52) and IL-6 trans-signaling appears to be only activated during immunological stress conditions, such as cancer. In addition to the increased secretion of IL-6 by the primary culture of RCC cells and the lack of natural inhibitor of enzymes which generate IL-6sR, it is possible that the IL-6sR/IL6 complex may play a role in the metastasis of ccRCC. An association has been reported between IL-6R $\alpha$ expression and lymphocyte antigen 75 (LY75) expression and the promotion of cellular adherence (53). These authors also claimed that this may be an additional mechanism by which IL6 signaling influences the progression of ovarian cancer, and they suggest that blocking LY75 may be a beneficial clinical strategy for inhibiting the early metastasis of cancer (53). Based on our results, we propose that in RCC metastatic development, the IL-6/IL-6sR complex seems to be responsible for the enhanced proliferation rate of RCC cells. A high secretion level of IL-6sR characteristic of malignant cells in comparison to normal renal cells seems to confirm the influence of IL-6/IL-6sR in renal cancer development (Figs. 19-22). The complex of IL-6 and its soluble receptor (IL-6sR; complex IL-6/IL-6sR) may be responsible for the crosstalk between cells and may determine metastatic homing.

Our results indicated that the zinc finger proteins are the most overexpressed genes in the NL-20 cell line co-cultured with Caki-2 and ACHN cells in comparison to monocultured NL-20 cells (Tables IV and V). The obtained data confirm alterations in normal cell signaling under the influence of cancer cells, changing functional cell properties to create a metastatic niche (Figs. 11-13 and 16-18). In the co-cultured cells (NL-20 and ACHN cells), we observed the perturbation of the IL-6 signaling pathway (Table III and Figs. 19-22), confirming that 
a tumor 'creates' a microenvironment and metastatic development is dominated by tumor-induced interactions, which is in accordance with conclusions broadly reviewed elsewhere (54). In particular, in normal pleural cells, multiple cancer-related networks (Tables I-III), were deregulated. These pathways may determine the most important proteins involved in RCC metastatic development (Tables IV and V).

Our study demonstrated that in the co-culture system of RCC and NL-20 cell lines, mostly genes connected with metastasis were deregulated. Microarray analysis of the NL-20 cells co-cultured with RCC indicated that the expression of MAPKKK activity was high and calcium ion signaling was deregulated, independent of whether the cells were co-cultured with metastatic or primary renal cancer cell lines. The deregulated genes are implicated in invasion and metastasis in other cancer types (55-58). The co-culture of healthy NL-20 and RCC cells also resulted in as many deregulated pathways in RCC cell lines. This indicates a greater impact of cancerous cells on normal cells than vice versa. Moreover, most differently activated pathways are often characteristic of renal biology including regulation of water balance by renal aquaporins, potassium channels, cation channel activity or passive transmembrane transporter activity (Tables VI-IX).

In recent years, the tumor microenvironment has received much attention from scientists due to its fundamental involvement in carcinogenesis, tumor growth, migration, invasion and immune escape by neoplastic cells from the host response. High throughput technologies for assaying gene expression, such as those used in the cDNA microarrays in the present study, may provide the ability to identify clinically relevant genes that are highly differentially expressed between different cell lines. Our results revealed an alteration of normal cell activity (e.g., gene expression) when cultured with cancer cells. Demonstrating the influence of cancerous cells on normal cells contributes to the development of a favorable niche for metastatic phenotype.

RCC cells induce the proliferation of lung epithelial cells upon interaction, and they, in turn, proliferate more rapidly. The crosstalk of RCC cells with normal lung cells results in the deregulation of multiple signaling pathways, including replication, mitotic division, cell cycling, cell motility, RNA biosynthetic process, and cell-cell communication. The identified signaling pathways may be considered as potentially 'druggable' in metastatic renal cancer. Cell-cell communications may contribute to the development of a favorable metastatic niche and promote disease progression. Nevertheless, the obtained results warrant further investigation and validation.

\section{Acknowledgements}

This study was supported by the Foundation for Polish Science TEAM project TEAM/2010-6/8 (C.S., K.K., A.M.C. and M.I.K.) and NCN UMO-2011/01/B/NZ4/01602 grant (K.K., A.M.C. and C.S.). W.F. received support from the Foundation for Polish Science First TEAM project financed by the Smart Growth Operational Program. We are grateful to Mr Roman Demianenko for providing technical support, and to Dr Aleksandra Fruba, Ms Magdalena Bucholc for providing administrative support. The authors would also like to thank the Experimental and Clinic Oncology Foundation (FODiK, Warsaw, Poland) for purchasing the necessary reagents.

\section{Competing interests}

The authors declare that they have no competing interests.

\section{References}

1. Coon JT, Hoyle M, Green C, Liu Z, Welch K, Moxham T and Stein K: Bevacizumab, sorafenib tosylate, sunitinib and temsirolimus for renal cell carcinoma: A systematic review and economic evaluation. Health Technol Assess 14: 1-184, 2010.

2. Schachter LR, Cookson MS, Chang SS, Smith JA Jr, Dietrich MS, Jayaram G and Herrell SD: Second prize: Frequency of benign renal cortical tumors and histologic subtypes based on size in a contemporary series: What to tell our patients. J Endourol 21: 819-823, 2007.

3. Bhat S: Role of surgery in advanced/metastatic renal cell carcinoma. Indian J Urol 26: 167-176, 2010.

4. Thyavihally YB, Mahantshetty U, Chamarajanagar RS, Raibhattanavar SG and Tongaonkar HB: Management of renal cell carcinoma with solitary metastasis. World J Surg Oncol 3: $48,2005$.

5. Miyata Y, Koga S, Kanda S, Nishikido M, Hayashi T and Kanetake H: Expression of cyclooxygenase-2 in renal cell carcinoma: Correlation with tumor cell proliferation, apoptosis, angiogenesis, expression of matrix metalloproteinase-2, and survival. Clin Cancer Res 9: 1741-1749, 2003.

6. Jemal A, Siegel R, Ward E, Hao Y, Xu J and Thun MJ: Cancer statistics, 2009. CA Cancer J Clin 59: 225-249, 2009.

7. Bruno JJ II, Snyder ME, Motzer RJ and Russo P: Renal cell carcinoma local recurrences: Impact of surgical treatment and concomitant metastasis on survival. BJU Int 97: 933-938, 2006.

8. Hanahan D and Coussens LM: Accessories to the crime: Functions of cells recruited to the tumor microenvironment. Cancer Cell 21: 309-322, 2012.

9. Spano D and Zollo M: Tumor microenvironment: A main actor in the metastasis process. Clin Exp Metastasis 29: 381-395, 2012.

10. Wang $X$ : Identification of common tumor signatures based on gene set enrichment analysis. In Silico Biol 11: 1-10, 2011-2012.

11. Brodaczewska KK, Szczylik C, Fiedorowicz M, Porta $C$ and Czarnecka AM: Choosing the right cell line for renal cell cancer research. Mol Cancer 15: 83, 2016.

12. Tanaka T, Torigoe T, Hirohashi Y, Sato E, Honma I, Kitamura H, Masumori N, Tsukamoto T and Sato N: Hypoxia-inducible factor (HIF)-independent expression mechanism and novel function of HIF prolyl hydroxylase-3 in renal cell carcinoma. J Cancer Res Clin Oncol 140: 503-513, 2014.

13. Gati A, Da Rocha S, Guerra N, Escudier B, Moretta A, Chouaib S, Angevin E and Caignard A: Analysis of the natural killer mediated immune response in metastatic renal cell carcinoma patients. Int J Cancer 109: 393-401, 2004

14. Hamburger AW, White CP and Dunn FE: Secretion of transforming growth factors by primary human tumour cells. Br J Cancer 51: 9-14, 1985.

15. Nakayama GR, Caton MC, Nova MP and Parandoosh Z: Assessment of the Alamar Blue assay for cellular growth and viability in vitro. J Immunol Methods 204: 205-208, 1997.

16. Boos DD and Stefanski LA: P-Value precision and reproducibility. Am Stat 65: 213-221, 2011.

17. Khan MI, Dębski KJ, Dabrowski M, Czarnecka AM and Szczylik C: Gene set enrichment analysis and ingenuity pathway analysis of metastatic clear cell renal cell carcinoma cell line. Am J Physiol Renal Physiol 311: F424-F436, 2016.

18. Khan MI, Czarnecka AM, Lewicki S, Helbrecht I, Brodaczewska K, Koch I, Zdanowski R, Król M and Szczylik C: Comparative gene expression profiling of primary and metastatic renal cell carcinoma stem cell-like cancer cells. PLoS One 11: e0165718, 2016.

19. Dresen IM, Hüsing J, Kruse E, Boes T and Jöckel KH: Software packages for quantitative microarray-based gene expression analysis. Curr Pharm Biotechnol 4: 417-437, 2003.

20. Savli H, Szendröi A, Romics I and Nagy B: Gene network and canonical pathway analysis in prostate cancer: A microarray study. Exp Mol Med 40: 176-185, 2008. 
21. Krämer A, Green J,Pollard J Jr and Tugendreich S: Causal analysis approaches in ingenuity pathway analysis. Bioinformatics 30 : 523-530, 2014

22. Harris MA, Clark J, Ireland A, Lomax J, Ashburner M, Foulger R, Eilbeck K, Lewis S, Marshall B, Mungall C, et al; Gene Ontology Consortium: The Gene Ontology (GO) database and informatics resource. Nucleic Acids Res 32: D258-D261, 2004.

23. Balakrishnan R, Harris MA, Huntley R, Van Auken K and Cherry JM: A guide to best practices for Gene Ontology (GO) manual annotation. Database (Oxford) 2013: bat054, 2013.

24. Kutmon M, Riutta A, Nunes N, Hanspers K, Willighagen EL, Bohler A, Mélius J, Waagmeester A, Sinha SR, Miller R, et al: WikiPathways: Capturing the full diversity of pathway knowledge. Nucleic Acids Res 44 (D1): D488-D494, 2016.

25. Network TCGAR; Cancer Genome Atlas Research Network: Comprehensive molecular characterization of clear cell renal cell carcinoma. Nature 499: 43-49, 2013.

26. Cancer Genome Atlas Research Network, Linehan WM, Spellman PT, Ricketts CJ, Creighton CJ, Fei SS, Davis C, Wheeler DA, Murray BA, et al: Comprehensive molecular characterization of papillary renal-cell carcinoma. N Engl J Med 374: $135-145,2016$

27. Kinnaird A and Michelakis ED: Metabolic modulation of cancer: A new frontier with great translational potential. J Mol Med (Berl) 93: 127-142, 2015.

28. Khan MI, Sobocińska AA, Czarnecka AM, Król M, Botta B and Szczylik C: The therapeutic aspects of the endocannabinoid system (ECS) for cancer and their development: From nature to laboratory. Curr Pharm Des 22: 1756-1766, 2016

29. Thoppil RJ and Bishayee A: Terpenoids as potential chemopreventive and therapeutic agents in liver cancer. World J Hepatol 3 : 228-249, 2011

30. Alizadeh J,Zeki AA, Mirzaei N, Tewary S, Rezaei Moghadam A, Glogowska A, Nagakannan P, Eftekharpour E, Wiechec E, Gordon JW, et al: Mevalonate cascade inhibition by simvastatin induces the intrinsic apoptosis pathway via depletion of isoprenoids in tumor cells. Sci Rep 7: 44841, 2017.

31. Damen JE, Liu L, Rosten P, Humphries RK, Jefferson AB Majerus PW and Krystal G: The 145-kDa protein induced to associate with Shc by multiple cytokines is an inositol tetraphosphate and phosphatidylinositol 3,4,5-triphosphate 5-phosphatase. Proc Natl Acad Sci USA 93: 1689-1693, 1996.

32. Guo H, German P, Bai S, Barnes S, Guo W, Qi X, Lou H, Liang J, Jonasch E, Mills GB, et al: The PI3K/AKT pathway and renal cell carcinoma. J Genet Genomics 42: 343-353, 2015.

33. Sun Z, Cao B and Wu J: Protease-activated receptor 2 enhances renal cell carcinoma cell invasion and migration via PI3K/AKT signaling pathway. Exp Mol Pathol 98: 382-389, 2015.

34. Yang $M$ and Huang CZ: Mitogen-activated protein kinase signaling pathway and invasion and metastasis of gastric cancer. World J Gastroenterol 21: 11673-11679, 2015.

35. Ellinger J,KahlP,Mertens C, Rogenhofer S, Hauser S,Hartmann W, Bastian PJ, Büttner R, Müller SC and von Ruecker A: Prognostic relevance of global histone $\mathrm{H} 3$ lysine $4(\mathrm{H} 3 \mathrm{~K} 4)$ methylation in renal cell carcinoma. Int J Cancer 127: 2360-2366, 2010.

36. Szatmári T and Dobra K: The role of syndecan-1 in cellular signaling and its effects on heparan sulfate biosynthesis in mesenchymal tumors. Front Oncol 3: 310, 2013.

37. Kamińska K, Szczylik C, Bielecka ZF, Bartnik E, Porta C, Lian F and Czarnecka AM: The role of the cell-cell interactions in cancer progression. J Cell Mol Med 19: 283-296, 2015.

38. Myszczyszyn A, Czarnecka AM, Matak D, Szymanski L, Lian F, Kornakiewicz A, Bartnik E, Kukwa W, Kieda C and Szczylik C: The role of hypoxia and cancer stem cells in renal cell carcinoma pathogenesis. Stem Cell Rev 11: 919-943, 2015.

39. Woodard J, Joshi S, Viollet B, Hay N and Platanias LC: AMPK as a therapeutic target in renal cell carcinoma. Cancer Biol Ther 10: $1168-1177,2010$.

40. Tong WH, Sourbier C, Kovtunovych G, Jeong SY, Vira M, Ghosh M, Romero VV, Sougrat R, Vaulont S, Viollet B, et al: The glycolytic shift in fumarate-hydratase-deficient kidney cancer lowers AMPK levels, increases anabolic propensities and lowers cellular iron levels. Cancer Cell 20: 315-327, 2011.
41. Li S, Priceman SJ, Xin H,Zhang W, Deng J, Liu Y, Huang J, Zhu W, Chen M, Hu W, et al: Icaritin inhibits JAK/STAT3 signaling and growth of renal cell carcinoma. PLoS One 8: e81657, 2013.

42. Chuang MJ, Sun KH, Tang SJ, Deng MW, Wu YH, Sung JS, Cha TL and Sun GH: Tumor-derived tumor necrosis factor-alpha promotes progression and epithelial-mesenchymal transition in renal cell carcinoma cells. Cancer Sci 99: 905-913, 2008.

43. Sievers E, Dreimuller P, Haferkamp A, Schmidt-Wolf IG, Buchler MW, Schmidt J and Marten A: Characterization of primary renal carcinoma cultures. Urol Int 79: 235-243, 2007.

44. Shariat SF, Andrews B, Kattan MW, Kim J, Wheeler TM and Slawin KM: Plasma levels of interleukin-6 and its soluble receptor are associated with prostate cancer progression and metastasis. Urology 58: 1008-1015, 2001.

45. Müllberg J, Schooltink H, Stoyan T, Günther M, Graeve L, Buse G, Mackiewicz A, Heinrich PC and Rose-John S: The soluble interleukin- 6 receptor is generated by shedding. Eur J Immunol 23: 473-480, 1993.

46. Müllberg J, Oberthür W, Lottspeich F, Mehl E, Dittrich E, Graeve L, Heinrich PC and Rose-John S: The soluble human IL-6 receptor. Mutational characterization of the proteolytic cleavage site. J Immunol 152: 4958-4968, 1994.

47. Kamińska K, Czarnecka AM, Escudier B, Lian F and Szczylik C: Interleukin-6 as an emerging regulator of renal cell cancer. Urol Oncol 33: 476-485, 2015.

48. Masson D, Rioux-Leclercq N, Fergelot P, Jouan F, Mottier S, Théoleyre S, Bach-Ngohou K, Patard JJ and Denis MG: Loss of expression of TIMP3 in clear cell renal cell carcinoma. Eur J Cancer 46: 1430-1437, 2010.

49. Kishimoto T: IL-6: From its discovery to clinical applications. Int Immunol 22: 347-352, 2010.

50. Mihara M, Hashizume M, Yoshida H, Suzuki M and Shiina M: IL-6/IL-6 receptor system and its role in physiological and pathological conditions. Clin Sci (Lond) 122: 143-159, 2012.

51. Matsumoto M, Tsujino T, Lee-Kawabata M, Naito Y, Sakoda T, Ohyanagi $M$ and Masuyama T: Serum interleukin-6 and $\mathrm{C}$-reactive protein are markedly elevated in acute decompensated heart failure patients with left ventricular systolic dysfunction. Cytokine 49: 264-268, 2010.

52. Jones SA, Horiuchi S, Topley N, Yamamoto N and Fuller GM The soluble interleukin 6 receptor: Mechanisms of production and implications in disease. FASEB J 15: 43-58, 2001.

53. Giridhar PV, Funk HM, Gallo CA, Porollo A, Mercer CA, Plas DR and Drew AF: Interleukin-6 receptor enhances early colonization of the murine omentum by upregulation of a mannose family receptor, LY75, in ovarian tumor cells. Clin Exp Metastasis 28: 887-897, 2011.

54. Whiteside TL: The tumor microenvironment and its role in promoting tumor growth. Oncogene 27: 5904-5912, 2008.

55. Eguchi D, Ohuchida K, Kozono S, Ikenaga N, Shindo K, Cui L, Fujiwara K, Akagawa S, Ohtsuka T, Takahata S, et al: MAL2 expression predicts distant metastasis and short survival in pancreatic cancer. Surgery 154: 573-582, 2013.

56. Russo J and Russo IH: The role of the basal stem cell of the human breast in normal development and cancer. Adv Exp Med Biol 720: 121-134, 2011.

57. Qin Q, Xu Y, He T, Qin C and Xu J: Normal and disease-related biological functions of Twist1 and underlying molecular mechanisms. Cell Res 22: 90-106, 2012.

58. Sun M, Song CX, Huang H, Frankenberger CA, Sankarasharma D, Gomes S, Chen P, Chen J, Chada KK, He C, et al: HMGA2/ TET1/HOXA9 signaling pathway regulates breast cancer growth and metastasis. Proc Natl Acad Sci USA 110: 9920-9925, 2013.

This work is licensed under a Creative Commons Attribution-NonCommercial-NoDerivatives 4.0 International (CC BY-NC-ND 4.0) License. 